\title{
Gender differences existing in the general population in relation to body dissatisfaction associated with the ideal of beauty: a systematic review / Diferencias de género existentes en la población general en relación a la insatisfacción corporal asociada al ideal de belleza: una revisión sistemática
}

\section{Adriana Sobrino-Bazaga \& María F. Rabito-Alcón}

To cite this article: Adriana Sobrino-Bazaga \& María F. Rabito-Alcón (2018): Gender differences existing in the general population in relation to body dissatisfaction associated with the ideal of beauty: a systematic review / Diferencias de género existentes en la población general en relación a la insatisfacción corporal asociada al ideal de belleza: una revisión sistemática, Estudios de Psicología, DOI: 10.1080/02109395.2018.1517860

To link to this article: https://doi.org/10.1080/02109395.2018.1517860

Published online: 05 Oct 2018.

Submit your article to this journal $\circlearrowright$

View Crossmark data 


\title{
Gender differences existing in the general population in relation to body dissatisfaction associated with the ideal of beauty: a systematic review / Diferencias de género existentes en la población general en relación a la insatisfacción corporal asociada al ideal de belleza: una revisión sistemática
}

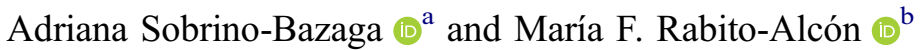 \\ ${ }^{a}$ Centro de Rehabilitación Laboral de Usera $;{ }^{b}$ UDIMA. Universidad a Distancia de Madrid
}

(Received 29 March 2018; accepted 28 August 2018)

\begin{abstract}
Body dissatisfaction has been studied extensively due to its relationship with issues such as eating disorders, mainly in the female and adolescent population. However, it seems that there are differences in the type of body dissatisfaction that females and males manifest with respect to their body image. On this basis, the objective of this work was to review systematically the studies published from 2010 to July 2018 into gender differences in body dissatisfaction associated with the ideal of beauty in the general population. A total of 18 studies were selected from the MeSH/ PubMed, Dialnet and DOAJ databases. The results obtained from the studies analysed showed that the female population continues to show greater body dissatisfaction associated with the ideal of beauty compared to the male population. However, the manifestation of body dissatisfaction is expressed differently for men and women.
\end{abstract}

Keywords: body image; personal satisfaction; sex distribution; beauty; body dysmorphic disorder

Resumen: La insatisfacción corporal se ha estudiado ampliamente por su relación con problemas como los trastornos de la conducta alimentaria. Principalmente, en población femenina y adolescente. Sin embargo, parece que existen diferencias en el tipo de insatisfacción que mujeres y hombres manifiesta respecto a su imagen corporal. En base a ello, el objetivo del trabajo es revisar de manera sistemática los estudios publicados desde el año 2010 hasta julio de 2018 sobre las diferencias de género en la insatisfacción corporal asociadas al ideal de belleza en población general. Un total de 18 estudios fueron seleccionados de las bases de datos MeSH/ PubMed, Dialnet y DOAJ. Los resultados obtenidos de los estudios analizados mostraron que es la población femenina quien continúa mostrando una

Authors' Address / Correspondencia con las autoras: María F. Rabito-Alcón, Facultad de Psicología, UDIMA, Universidad a Distancia de Madrid, Vía de Servicio A-6, 15, 28400, Collado Villalba, Madrid, España. E-mail: mariafrenzi.rabito@udima.es

English version: pp. 1-18 / Versión en español: pp. 19-36

References / Referencias: pp. 37-40

Translated from Spanish / Traducción del español: Liza D’Arcy 
mayor insatisfacción corporal asociada al ideal de belleza respecto a la masculina. Sin embargo, la manifestación de insatisfacción corporal es expresada de manera diferente para hombres y mujeres.

Palabras clave: imagen corporal; satisfacción personal; distribución de sexo; belleza; trastorno dismórfico corporal

The influence the media and advertising play in the transmission of bodily aesthetic models has given the concept of body image a greater impact. However, the models presented, and sometimes even imposed, differ in terms of gender and exert a different sociocultural pressure for females and males (Oliveira \& Parra, 2013).

Body image is a multidimensional concept that has been studied throughout history and whose conceptualization has always been evolving, especially since the beginning of the twentieth century (Baile, 2003; Rabito-Alcón \& RodríguezMolina, 2015, 2016).

Through integrating different perspectives and a compendium of contributions made by different authors, Raich (2004) defines body image as a complex psychological construct that includes the perception a person has of their whole body and each of its parts, and in turn its movements and limits, while also comprising that person's subjective experience deriving from their attitudes, thoughts, feelings, evaluations and, consequently, the way they behave because of those cognitions and feelings being experienced. Therefore, when a person perceives that their body image does not match or does not correspond to the 'ideal of beauty' or 'prevailing aesthetic body models', they have a greater probability of manifesting body dissatisfaction (Rabito-Alcón \& RodríguezMolina, 2015).

Body dissatisfaction refers to a person's discomfort and dissatisfaction with their own body, either by overestimating, undervaluing or a distortion of their body proportions in a negative way in relation to specific parts of their whole body or part of it (Baile \& Velázquez-Castañeda, 2006; Sepúlveda, Botella, \& León, 2001). Cash and Pruzinsky (2002) simplify this definition to a person's discrepancies between their self-perceived body image and their ideal body image.

Furthermore, body dissatisfaction has been found to be a risk factor and good predictor of eating disorders (ED), mainly in the female and adolescent population (Baile, Raich, \& Garrido, 2003; Gómez \& Veiga, 2007; González, García, \& Martínez, 2013; Rodríguez-Ruiz et al., 2013; Trujano et al., 2010). However, research carried out over the last decade has found that the trend of this population being the most affected is changing, as results show that the male population also manifests feelings of being dissatisfied with their body image when they believe they are no longer in line with the prevailing concept of a masculine body model (Magallares, 2016; Vázquez, López-Aguilar, Álvarez-Rayón, Manzilla, \& Oliva, 2016).

Esnaola, Rodríguez, and Goñi (2010) found that the more pressure people perceived regarding an idealized body image, regardless of whether they are female or male, the greater the concern for body image. Consequently, strategies 
aimed at changing people's body models appear, which can sometimes result in people putting their health at risk.

We can thus conclude that body dissatisfaction is a variable that has significant individual and social consequences, and that it is made up of individual, social and cultural factors, each with different weightings. Among these, 'aesthetic body models' are particularly relevant (Amaya, Álvarez, \& Mancilla, 2010; Bully, Elosua, \& López-Jáuregui, 2012).

When we refer to the concept of current beauty, we refer to Esposito's (2015) stereotypes of the 'ideal body', built in a social way and promoted by media and advertising as a canon of 'beautiful bodies' or as 'bodies that we should all aspire to have'. These models, which are imposed as the only valid ones, would be accentuating body dissatisfaction and increasing levels of body image dissatisfaction.

According to Cruz and Maganto (2008), these corporal models exalt, for females, extremely thin bodies that do not have rounded shapes or curves, androgynous and angular bodies, where sexual characteristics seem to be blurred. For men, the ideal of beauty focuses on athletic bodies, with developed pectorals and abdominals, broad shoulders and narrow waists.

As we can see, gender plays a fundamental role in the way males and females perceive, feel or value, at a general level, their body and body image. In the case of females, a greater importance is given to physical beauty, personal appearance and sexual attractiveness. By contrast, the ideal image for males is established through other types of skills associated with strength and virility (Esnaola, 2005; Raich, 2000; Vaquero, Macías, \& Macazaca, 2014).

Previous research, such as the studies outlined below, found that although social pressure in favour of thinness has been greater in the female population, it is a phenomenon that can also be evidenced in the male population. In this regard, Trejo, Castro, Facio, Mollinedo, and Valdez (2010) highlight that, for females, society and the media foster a slim image, which results in women wanting to lose weight to fit the 'concept of a slim beauty'. For males, the media project 'muscular models' that result in men wanting to increase their muscle mass. Along the same line, Trujano et al. (2010) found evidence that current stereotypes of 'extreme thinness' continue to impact more on the female sex than on males, who seek to be thin while simultaneously having big muscles.

Motivated by gender differences associated with the ideal of beauty found in previous research, Amaya et al. (2010) carried out a review of studies made during the 2000 to 2009 period using the adolescent population; they concluded that body dissatisfaction differs in terms of gender, especially in adolescence. These authors suggest that body dissatisfaction may also have its origin in the desire for greater weight and/or muscle tone, regardless of gender. Based on these results, they pointed out the need to continue examining gender differences and different types of body dissatisfaction. A second review that ranged from the period between 1990 and 2011 and was aimed at understanding the precursor variables of body dissatisfaction in children and adolescents found that both sexes showed high levels of body dissatisfaction as well as concern for weight and 
shape. These variables presented differently for females and males (Mancilla, Vázquez, Mancilla, Amaya, \& Álvarez, 2012).

Given the diversity of studies and reviews that show differences between gender and age in how body dissatisfaction associated with the ideal of beauty is manifested, and the absence of data found in the non-clinical adult population regarding this subject, we carried out a systematic review of studies into this area published between 2010 and 2018 with the purpose of understanding current differences between the genders regarding body dissatisfaction associated with the ideal of beauty in the general population older than 18 .

\section{Method}

\section{Sample and selection of papers}

Figure 1 describes the procedure that was used to search for publications on body dissatisfaction associated with the ideal of beauty during the 2010 to July 2018 period on the aforementioned databases - MeSH/PubMed, Dialnet and DOAJ introducing as keywords the indexed terms in MeSH/PubMed — 'Body Image', 'Body Dysmorphic Disorders', 'Personal Satisfaction', 'Sex Distribution', 'Beauty' — in different combinations.

The selection of papers was carried out by applying several inclusion and exclusion criteria that are detailed in Table 1.

\section{Results}

\section{Selected articles}

The total number of papers retrieved after entering the indexed terms was 2,292. We filtered them by year of publication between 2010-18, studies that used samples of males and females aged over 18 and availability of the full text, reducing the number of publications to 117 . The search for articles was updated until 15 July 2018.

After exhaustively reading all the studies filtered by the databases, a total of 18 publications, shown in Table 2, were selected. These papers meet all the inclusion and none of the exclusion criteria.

\section{Analysis of papers}

Year of publication

A progressive increase was observed in the number of publications during the 2010 to mid-July 2018 search period selected for scientific reasons. 2013 (Bucchianeri, Arikian, Hannan, Eisenberg, \& Neumark-Sztainer, 2013; Garrusi \& Baneshi, 2013; González et al., 2013; Siegling \& Delaney, 2013) and 2016 (Berengüí, Castejón, \& Torregrosa, 2016; Chng \& Fassnacht, 2016; Salcedo, 2016; Zueck, Pinto, Pando, \& Guedea, 2016) had the highest number of publications, with four articles per year. Following those years was 2015 


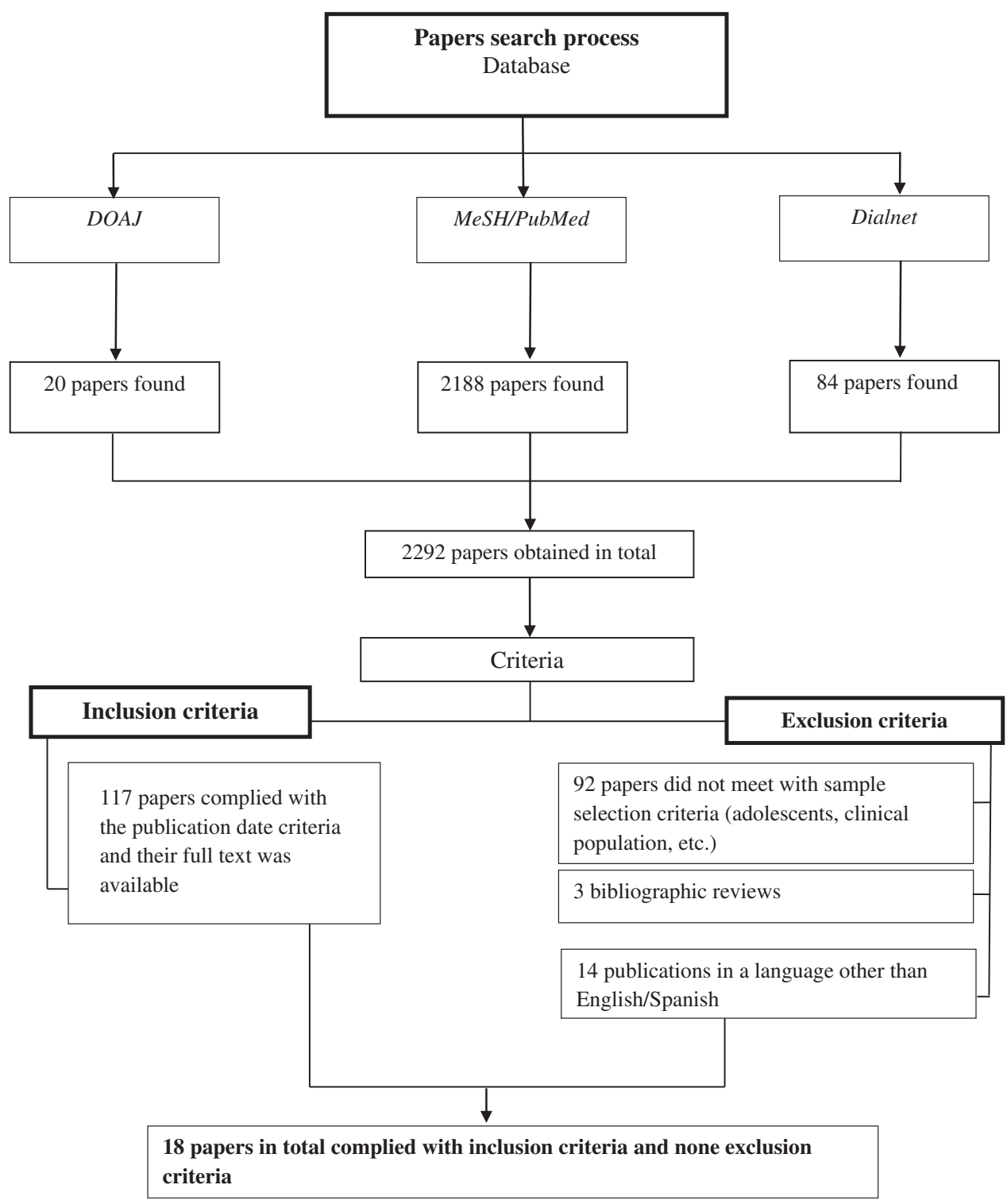

Figure 1. Representation of the systematic steps taken for the selection of papers which our study used, based on inclusion/exclusion criteria.

with three publications (Ejike, 2015; Mintem, Gigante, \& Horta, 2015; Salvador, García-Gálvez, \& De La Fuente, 2015), 2012 with two (ForresterKnauss \& Stutz, 2012; Gillen \& Lefkowitz, 2012) and 2010 (Esnaola et al., 2010), 2011 (Arbinaga, García, Vázquez, Joaquín, \& Pazos, 2011), 2014 (Zaccagni, Masotti, Donati, Mazzoni, \& Gualdi-Russo, 2014), 2017 (Garrusi \& Baneshi, 2017) and 2018 (Salgado \& Álvarez, 2018), with one publication each. 
Table 1. Inclusion/exclusion criteria.

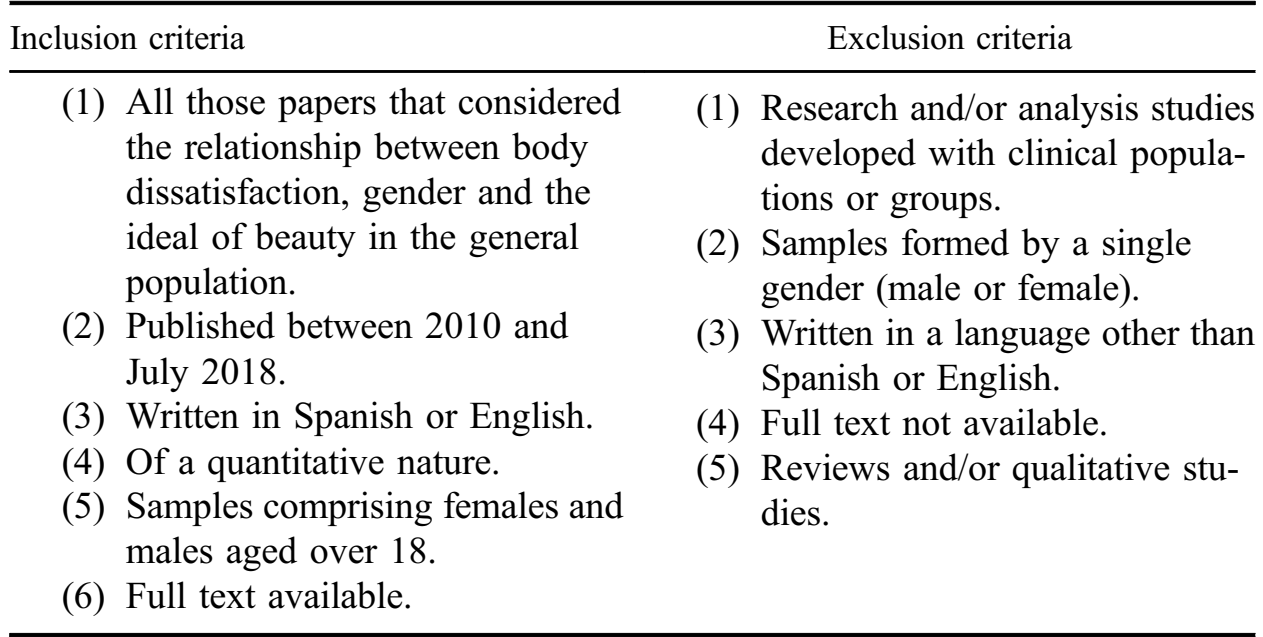

\section{Journals}

The journals that published the greatest number of publications on gender differences in body dissatisfaction associated with the ideal of beauty were Body Image, which had published 16.67\% of the selected studies (Bucchianeri et al., 2012; Chng \& Fassnacht, 2016; Gillen \& Lefkowitz, 2012), and BMC Public Health, with 11.11\% (Forrester-Knauss \& Stutz, 2012; Mintem et al., 2015). The other articles were published by different journals.

\section{Objectives}

As can be seen in Table 2, the general purpose of the majority of the studies was to understand and evaluate the gender differences in regard to body dissatisfaction associated with the ideal of beauty. In addition, there were other variables related to body dissatisfaction, such as: body mass index (BMI) and weight perception (Bucchianeri et al., 2013; Chng \& Fassnacht, 2016; Ejike, 2015; Forrester-Knauss \& Stutz, 2012; Garrusi \& Baneshi, 2017; Mintem et al., 2015; Salcedo, 2016; Salgado \& Álvarez, 2018; Siegling \& Delaney, 2013), sociocultural pressures (Esnaola et al., 2010; Gillen \& Lefkowitz, 2012), eating habits (Arbinaga et al., 2011), ED risk development (Garrusi \& Baneshi, 2013), cognitive factors such as perfectionism (Siegling \& Delaney, 2013), risk behaviours and/or compensatory behaviours (Berengüi et al., 2016), the practice of physical activity (Arbinaga et al., 2011; González et al., 2013; Zaccagni el at., 2014) and the influence of parental comments (Chng \& Fassnacht, 2016) in the development of body dissatisfaction. 
Table 2. Selected papers about body dissatisfaction in the general population published between 2010 and 2018 .

\begin{tabular}{|c|c|}
\hline Study & Objective \\
\hline Esnaola et al. (2010) & $\begin{array}{l}\text { To examine the relationship } \\
\text { gender and age have with } \\
\text { body image and perceived } \\
\text { sociocultural pressures with } \\
\text { regard to the ideals of body } \\
\text { from adolescence to old age. }\end{array}$ \\
\hline
\end{tabular}

Arbinaga et al. (2011) Provide data on university students' attitudes and their possible relationships with eating habits and body image satisfaction.

Forrester-Knauss and Examine the prevalence of Stutz (2012) dissatisfaction with weight, disordered eating and sociodemographic factors in males and females.

The variable of gender is more significant than that of age when explaining differences in body dissatisfaction. Males manifest less body dissatisfaction and feel less influenced by aesthetic body models than females.

Females show greater body dissatisfaction as opposed to males, and those who carry out more physical exercise are more satisfied with their body image.

More than half the females and males studied wanted to change their weight. For the majority, females wanted to lose weight and males wanted to increase their muscle mass.

Gillen and Lefkowitz Examine whether there are (2012) changes in body image during university and whether there are gender differences and racial groups/ ethnicities.

University males were more satisfied with their appearance than females. The effect of time was the only significant variable for the university students, who became increasingly satisfied with their appearance as time progressed.

Bucchianeri et al. (2013)

Address evidence regarding the evolution of body dissatisfaction during the transitions between adolescence and adulthood.

Garrusi and Baneshi Explore the prevalence of eating (2013) disorders and their risk factors in the Iranian population.

Participants became progressively more dissatisfied with their bodies over a period of 10 years.

Body dissatisfaction was considered a central problem in the development of eating disorders, but its effect was not obvious in females.

González et al. (2013) Evaluate eating behaviours and Females had higher levels of body image in the university population. body dissatisfaction than males, wanted to weigh less and were more concerned about their body image.

Siegling and Delaney Examine the role of cognitive (2013) perfectionism and gender schemas associated with the importance given to body image (BII).

Evidence that BII and body satisfaction are associated as a function of perfectionism. As well as the interaction of sex and gender schema with BII. 
Table 2. (Continued).

\begin{tabular}{|c|c|c|}
\hline Study & Objective & Results \\
\hline Zaccagni et al. (2014) & $\begin{array}{l}\text { Examine the perception of body } \\
\text { image, degree of } \\
\text { dissatisfaction and } \\
\text { inconsistency of the } \\
\text { perception of weight in a } \\
\text { sample of university students. }\end{array}$ & $\begin{array}{l}\text { Dissatisfaction with body image } \\
\text { affects both genders and is } \\
\text { influenced by both culture } \\
\text { and society, which often } \\
\text { favour models close to those } \\
\text { of people suffering from } \\
\text { anorexia. }\end{array}$ \\
\hline Ejike, C. E (2015) & $\begin{array}{l}\text { Explore the prevalence of } \\
\text { weight preference and } \\
\text { dissatisfaction with body } \\
\text { image among Nigerians. }\end{array}$ & $\begin{array}{l}\text { More than half the sample } \\
\text { indicated that they were } \\
\text { dissatisfied with their body } \\
\text { image. }\end{array}$ \\
\hline $\begin{array}{l}\text { Garrusi and Baneshi } \\
\text { (2017) }\end{array}$ & $\begin{array}{l}\text { Evaluate general body } \\
\text { dissatisfaction and identify } \\
\text { factors that could affect body } \\
\text { dissatisfaction in Iranians. }\end{array}$ & $\begin{array}{l}\text { About two-thirds of the } \\
\text { participants had some degree } \\
\text { of body dissatisfaction, with } \\
\text { a positive correlation } \\
\text { between BMI and body } \\
\text { dissatisfaction, suggesting } \\
\text { that an increase in BMI is } \\
\text { associated with an increase in } \\
\text { body dissatisfaction. }\end{array}$ \\
\hline $\begin{array}{l}\text { Salgado and Álvarez } \\
\text { (2018) }\end{array}$ & $\begin{array}{l}\text { Compare, between males and } \\
\text { females, aspects related to } \\
\text { body image, BMI and (dis) } \\
\text { satisfaction with body image, } \\
\text { and explore the way in which } \\
\text { they see themselves (Real } \\
\text { self), how they would like to } \\
\text { see themselves (Ideal self) } \\
\text { and how they see their peers. }\end{array}$ & $\begin{array}{l}\text { Greater prevalence of } \\
\text { overweight/obesity in males, } \\
\text { and a greater proportion of } \\
\text { females are concerned about } \\
\text { gaining weight and want to } \\
\text { change some part of their } \\
\text { body; females reported more } \\
\text { dissatisfaction with their } \\
\text { body image through a desire } \\
\text { to lose weight, regardless of } \\
\text { their BMI. }\end{array}$ \\
\hline
\end{tabular}

\section{Scenario}

Nearly $80 \%$ of the publications came from Western countries, including: $27.78 \%$ from Spain (Arbinaga et al., 2011; Berengüí et al., 2016; Esnaola et al., 2010; González et al., 2013; Salvador et al., 2015), 11.11\% from the US (Bucchianeri et al., 2013; Gillen \& Lefkowitz, 2012), 5.56\% from Sweden (Forrester-Knauss \& Stutz, 2012), 5.56\% from Canada (Siegling \& Delaney, 2013) and 5.56\% from Italy (Zaccagni et al., 2014). Regarding South American countries, $11.11 \%$ of the publications came from Mexico (Salgado \& Álvarez, 2018; Zueck et al., 2016), $11.11 \%$ from Brazil (Mintem et al., 2015) and 11.11\% from Colombia (Salcedo, 2016). The remaining $16.67 \%$ of the publications came from Eastern countries: 
$11.11 \%$ from Iran (Garrusi \& Baneshi, 2013, 2017) and 5.56\% from Singapore (Chng \& Fassnacht, 2016).

Of these, $50 \%$ of the research was carried out in university environments (Arbinaga et al., 2011; Berengüí et al., 2016; Ejike, 2015; Gillen \& Lefkowitz, 2012; González et al., 2013; Salcedo, 2016; Salvador et al., 2015; Zaccagni et al., 2014; Zueck et al., 2016).

\section{Sample}

The sample sizes, described in Table 3, ranged between 89 (González et al., 2013) and 18,156 participants (Forrester-Knauss \& Stutz, 2012). There was a significantly greater number of females than males, with the exception of four publications (Ejike, 2015; Garrusi \& Baneshi, 2017; Salgado \& Álvarez, 2018; Zaccagni et al., 2014).

Regarding the age of the participants, $16.67 \%$ of the research studies used age groups ranging from adolescence and adulthood (Bucchianeri et al., 2013; Esnaola et al., 2010; Garrusi \& Baneshi, 2017), of which only the results of those groups with participants older than 18 were used. The other studies used a single group whose participants were of legal age.

Of the studies analysed, $66.67 \%$ indicated the average age of the sample (Berengüí et al., 2016; Bucchianeri et al., 2013; Chng \& Fassnacht, 2016; Ejike, 2015; Esnaola et al., 2010; Garrusi \& Baneshi, 2013, 2017; Mintem et al., 2015; Salgado \& Álvarez, 2018; Salvador et al., 2015; Siegling \& Delaney, 2013; Zueck et al., 2016), where the highest was 50.7 (ForresterKnauss \& Stutz, 2012). In addition to the data relative to the total age of the sample, $22.22 \%$ also provided data on the mean of each group based on gender, thus differentiating between female and male (Arbinaga et al., 2011; ForresterKnauss \& Stutz, 2012; Gillen \& Lefkowitz, 2012; González et al., 2013).

The remaining $11.11 \%$ only indicated an age range from which the participants were selected (Garrusi \& Baneshi, 2013; Salcedo, 2016).

\section{Instruments}

Table 4 shows the evaluation tools used by the different research studies analysed to evaluate and measure body dissatisfaction associated with the ideal of beauty.

Although there is a wide range of instruments available to evaluate body dissatisfaction, the tools most commonly used by the selected articles were Body Shape Questionnaire (BSQ) by Cooper, Taylor, Cooper, and Fairburn (1987), which was used by $22.22 \%$ of the selected publications (Arbinaga et al., 2011; Bucchianeri et al., 2013; González et al., 2013; Salcedo, 2016), Figure Rating Scale (FRS) by Stundarkd, Sorensen, and Schulsinger (1983), used by $22.22 \%$ of the articles (Ejike, 2015; Garrusi \& Baneshi, 2013, 2017; Mintem et al., 2015) and Eating Disorder Inventory (EDI) by Garner (1990) in its 1990 EDI-2 revised versions, translated into Spanish (Corral, González, Pereña, \& Seisdedos, 1998) (Esnaola et al., 2010), and the version revised in 2004 (EDI-3), 
Table 3. Distribution by gender and age of the samples studied by the selected papers.

\begin{tabular}{|c|c|c|c|c|}
\hline \multirow[b]{2}{*}{ Study } & \multicolumn{3}{|c|}{ Sample } & \multirow[b]{2}{*}{ Description (Age) } \\
\hline & Females & Males & Total & \\
\hline Esnaola et al. (2010) & 702 & 557 & 1,259 & $\begin{array}{l}\text { Four age groups: } 627 \text { adolescents } \\
\text { (12-18 years old, } M=15.33), 272 \\
\text { young adults }(19-30 \text { years old, } \\
M=22.50), 248 \text { middle-aged } \\
\text { adults }(31-49 \text { years old, } \\
M=39.88) \text { and } 112 \text { older adults, } \\
\text { aged over } 55(M=60.36)\end{array}$ \\
\hline Arbinaga et al. (2011) & 105 & 55 & 160 & $\begin{array}{l}M=20.76 \text { years old }(\text { Females } \\
\quad M=21.81, \text { Males }, M=20.23)\end{array}$ \\
\hline $\begin{array}{l}\text { Forrester-Knauss and } \\
\text { Stutz (2012) }\end{array}$ & 9,516 & 7,570 & 18,156 & $\begin{array}{l}M=50.7 \text { years old }(\text { Females } \\
\quad M=51.56, \text { Males, } M=49.60)\end{array}$ \\
\hline $\begin{array}{l}\text { Gillen and Lefkowitz } \\
\text { (2012) }\end{array}$ & 210 & 180 & 390 & $\begin{array}{l}M=19.50 \text { years old (Females, } \\
\quad M=19.44, \text { Males, } M=19.57)\end{array}$ \\
\hline $\begin{array}{l}\text { Bucchianeri et al. } \\
\text { (2013) }\end{array}$ & 1083 & 819 & 1,902 & $M=23.2$ years old \\
\hline $\begin{array}{l}\text { Garrusi and Baneshi } \\
\text { (2013) }\end{array}$ & 640 & 541 & 1,181 & $M=31.06$ years old \\
\hline González et al. (2013) & 64 & 25 & 89 & $\begin{array}{l}M=23.8 \text { years old }(\text { Females, } \\
\quad M=25.12, \text { Males }, M=23.36)\end{array}$ \\
\hline $\begin{array}{l}\text { Siegling and Delaney } \\
\text { (2013) }\end{array}$ & 110 & 30 & 141 & $M=20.18$ years old \\
\hline Zaccagni et al. (2014) & 354 & 380 & 734 & Females, $M=21.5 ;$ Males, $M=22.1$ \\
\hline Ejike (2015) & 2,000 & 380 & 2,380 & $M=21.7$ years old \\
\hline Mintem et al. (2015) & 1,739 & 1,963 & 3,702 & $M=22.7$ years old \\
\hline Salvador et al. (2015) & 505 & 235 & 740 & $\begin{array}{l}\text { Three age groups: } 453 \text { younger } \\
\text { people (18-20 years old), } 258 \\
\text { young adults }(21-30 \text { years old }) \text { and } \\
\text { adults ( } 31-51 \text { years old): } \\
M=21.15 \text { years old }\end{array}$ \\
\hline Berengüí et al. (2016) & 148 & 116 & 264 & $M=22.62$ years old \\
\hline $\begin{array}{l}\text { Chng and Fassnacht } \\
\text { (2016) }\end{array}$ & 265 & 118 & 383 & $M=21.2$ years old \\
\hline Salcedo (2016) & 152 & 48 & 200 & Between 18 and 25 years old \\
\hline Zueck et al. (2016) & 871 & 706 & 1,577 & $M=20.64$ years old \\
\hline $\begin{array}{l}\text { Garrusi and Baneshi } \\
\text { (2017) }\end{array}$ & 635 & 549 & 2,014 & $\begin{array}{l}\text { Three age groups: } 187(<20 \text { years } \\
\text { old }), 783(20-40 \text { years old }), 213 \\
(>40 \text { years old }) ;(M=31.06)\end{array}$ \\
\hline $\begin{array}{l}\text { Salgado and Álvarez } \\
\text { (2018) }\end{array}$ & 168 & 132 & 300 & $M=20.53$ years old \\
\hline Total & 19,264 & 14,404 & 35,572 & \\
\hline
\end{tabular}

Note: $M=$ Mean age. Description of the samples selected by the papers analysed, ordered by year of publication. 


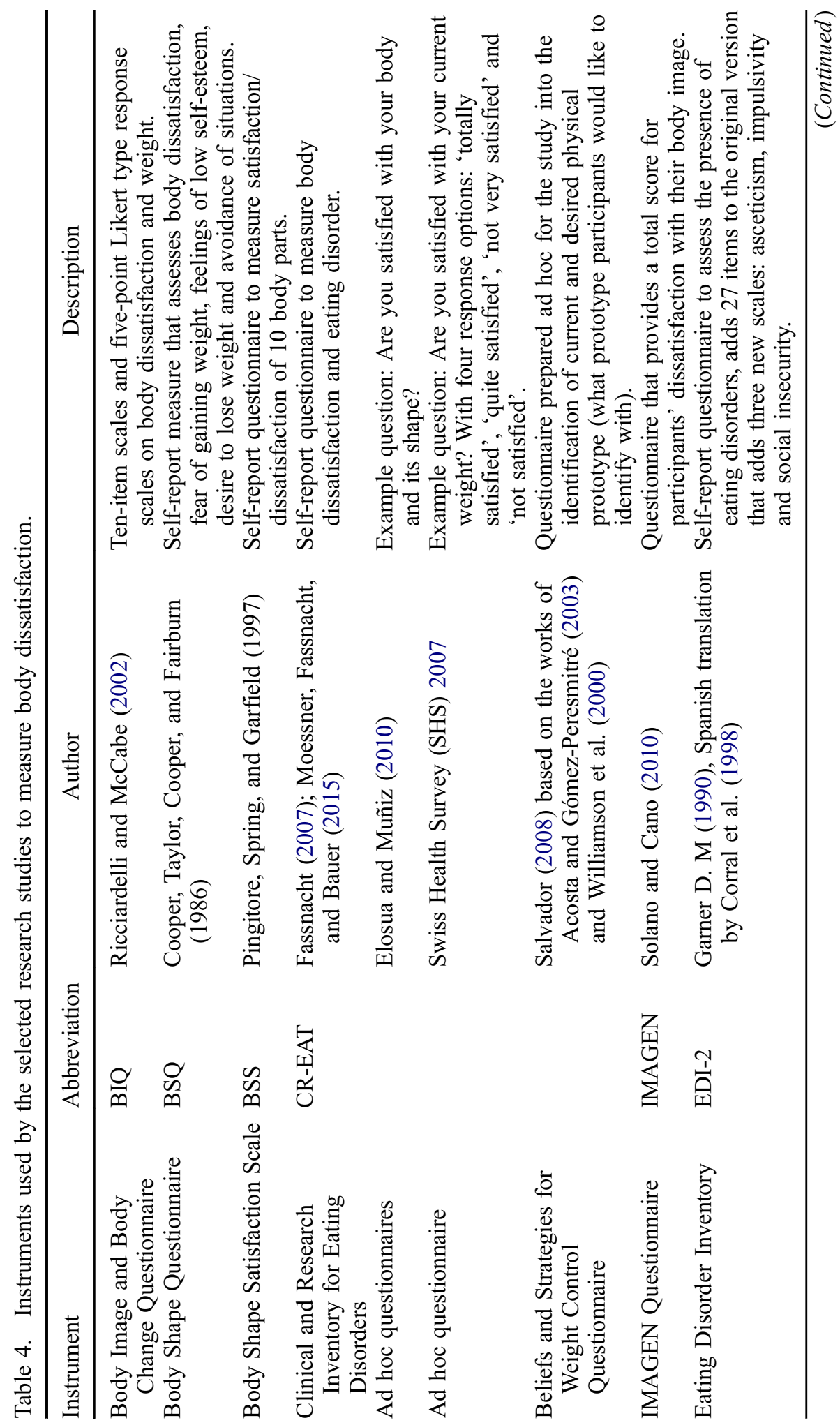




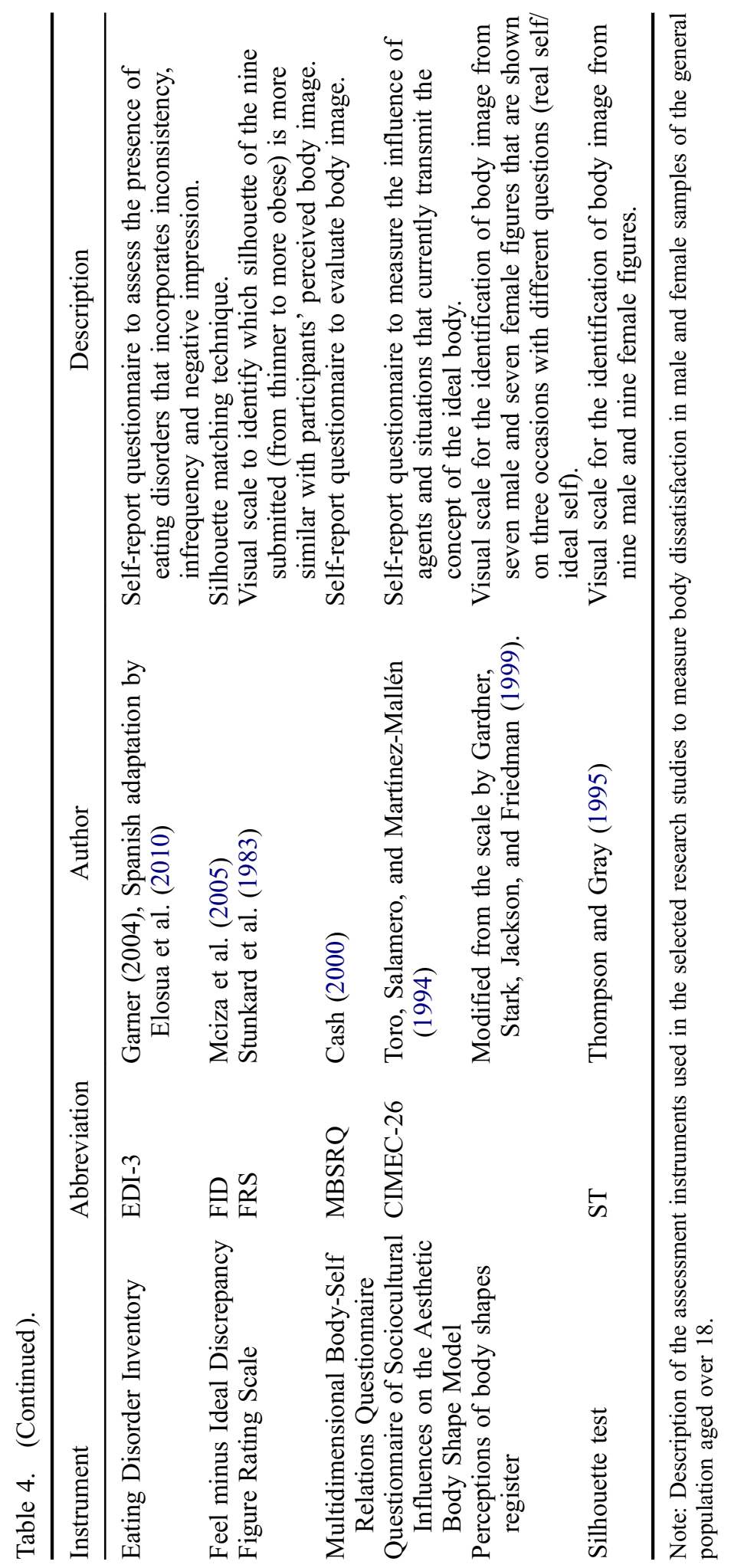


translated by Elosua, López-Jáuregui, and Sánchez-Sánchez (2010) (Berenguí et al., 2016).

The remaining $50 \%$ of the selected research studies used self-report tools (Chng \& Fassnacht, 2016; Gillen \& Lefkowitz, 2012; Siegling \& Delaney, 2013), visual scales (González et al., 2013; Salgado \& Álvarez, 2018; Zaccagni et al., 2014) and ad hoc questionnaires specifically prepared for the study to evaluate body dissatisfaction associated with the ideal of beauty which used closed questions with response options (Berengüí et al., 2016; Forrester-Knauss \& Stutz, 2012; Salvador et al., 2015).

In addition to body dissatisfaction, the selected papers studied its interaction with other variables. $44.44 \%$ of the selected studies used participants' BMI data, which they obtained through self-reported weight and height measurements (Bucchianeri et al., 2013; Ejike, 2015; Forrester-Knauss \& Stutz, 2012; Garrusi \& Baneshi, 2013; Mintem et al., 2015; Salcedo, 2016; Álvarez, 2018; Zaccagni et al., 2014); other studies included variables such as self-esteem (Garrusi \& Baneshi, 2013; Salvador et al., 2015), attitude towards food or eating habits (Arbinaga et al., 2011;Chng \& Fassnacht, 2016; Forrester-Knauss \& Stutz, 2012; González et al., 2013), the practice of physical activity (Arbinaga et al., 2011; Zaccagni et al., 2014; Zueck et al., 2016) and the relationship between the 'Real self' and the 'Ideal self' (Salgado \& Álvarez, 2018).

\section{Research findings}

With the purpose of examining the prevalence rates of body dissatisfaction associated with the ideal of beauty in females and males, the results obtained by $72.22 \%$ of the research studies analysed showed that there are significant differences in terms of body dissatisfaction between males and females regarding their body image associated with the ideal of beauty: the female population reported greater dissatisfaction with their body image and weight than males (Arbinaga et al., 2011; Chng \& Fassnacht, 2016; Ejike, 2015; Esnaola et al., 2010; ForresterKnauss \& Stutz, 2012; Garrusi \& Baneshi, 2017; Gillen \& Lefkowitz, 2012; González et al., 2013; Mintem et al., 2015; Salgado \& Álvarez, 2018; Salvador et al., 2015; Zaccagni et al., 2014; Zueck et al., 2016). In contrast, Garrusi and Baneshi (2013) did not find significant differences by gender.

Regarding the relationship between the age of the subjects and the level of body dissatisfaction, the studies analysed reported that females and males felt more dissatisfied during the period stretching from adolescence to adulthood and that, as time passes, body dissatisfaction begins to decrease with age until it stabilizes (Berengüí et al., 2016; Bucchianeri et al., 2013; Salcedo, 2016; Zaccagni et al., 2014).

In order to analyse whether there are differences between genders in regard to body dissatisfaction associated with the ideal of beauty, the results of the research studies showed that body dissatisfaction occurred when males and females tried to match their body image to the ideal of beauty and that the dissatisfaction that each gender showed differed on the basis of aesthetic body 
models: for males, there was a drive towards increasing muscles and for females towards being skinny.

Specifically, $22.22 \%$ of the research studies found a greater desire in males to increase their muscle mass and in females to lose weight (Ejike, 2015; ForresterKnauss \& Stutz, 2012; Salgado \& Álvarez, 2018; Zaccagni et al., 2014).

Gillen and Lefkowitz (2012) considered that the bodies of females were culturally objectified and that the consequent self-objectification can lead this population to be excessively critical towards their bodies, resulting in this group's perception of their appearance to be poorer than males. In addition, Zueck et al. (2016) believed that the standards of 'beauty and thinness' are much more rigid for females than for males.

Finally, with the aim of exploring the influence of different variables on body dissatisfaction associated with the ideal of beauty, in general, gender was a more significant variable than age (Esnaola et al., 2010). However, these were not the only predictors of body dissatisfaction found.

Predictors of body dissatisfaction in the female population included low weight, smoking, ethnicity and physical activity (Arbinaga et al., 2011; Forrester-Knauss \& Stutz, 2012; Zaccagni et al., 2014), while for both sexes a disordered eating behaviour was shown to be a significant predictor of body dissatisfaction (Chng \& Fassnacht, 2016; González et al., 2013).

Other variables that showed evidence of the development of body dissatisfaction were parental comments on body image for both genders in the Asian population (Chng \& Fassnacht, 2016), the practice of sports and physical activity (Arbinaga et al., 2011; Forrester-Knauss \& Stutz, 2012), BMI (Bucchianeri et al., 2013) and psychological variables such as perfectionism (Siegling \& Delay, 2013) and low self-esteem (Zaccagni et al., 2014) as mediating or moderating variables for the development of body dissatisfaction.

\section{Discussion}

The results of $72.22 \%$ of the research studies analysed showed that females had higher levels of body dissatisfaction than males, with a desire to lose weight and to adjust their body image to prevailing aesthetic body models and ideals of beauty in favour of thinness fostered by the media. These results concur with what has already been reported by previous reviews into body dissatisfaction associated with the ideal of beauty (Mancilla et al., 2012; McCabe \& Ricciardelli, 2004).

However, we must be cautious when interpreting the results, as there is no clear balance between the sample number of females and males participating in such studies (the volume of the female population studied was significantly greater than the male population). One possible reason for this could be that throughout history, females have always been considered as most vulnerable and most at risk of developing eating disorders (Amaya et al., 2010; Laus et al., 2014). Studies that did take into account the limitations of the samples — an unbalanced proportion of females and males - found that the male population also feels dissatisfied with their body image, manifesting, as females do, a greater desire to 
lose weight or stay slim, along with a desire to increase their muscle mass. In this regard, it is also worth mentioning that during the twenty-first century, the cult of the body has contributed to an increase of other associated disorders that are more characteristic of the male population and also associated with body dissatisfaction, such as Muscle Dysmorphia (MD) or Vigorexia. This is mainly characterized by an obsession to achieve body perfection through the development of muscle mass (Rodríguez-Molina \& Rabito-Alcón, 2011).

Another point worth noting was that over $50 \%$ of the research studies analysed were carried out using university group samples, which limits the generalization of the results to other groups.

We can generally conclude that the studies measured body dissatisfaction as a global index, without distinguishing between any differences that might exist between females and males. Overall, approximately $60 \%$ of the samples selected expressed feeling dissatisfied with their body. For Zueck et al. (2016), these results corroborate that body dissatisfaction is a health problem that predisposes people to the development of certain disorders such as ED or MD (Compte \& Sepúlveda, 2014).

In regard to the research scenario, most of the studies analysed originated in Europe and the USA, which is partly explained by the fact that only publications written in Spanish and English were selected. However, other research studies reported an increase in the prevalence of eating disorders, especially in developed or developing countries, although it is still a practically non-existent problem in third-world countries (Ministry of Health and Consumer Affairs, 2009). The increase of such prevalence can also be related to a progressive increase of research carried out between the years 2010 and 2018. However, it is important to note that cases of eating disorders are becoming more frequent in developing countries. A possible reflection of this fact may be the increase in the number of research studies in South American countries such as Mexico and Colombia, in addition to Singapore or even Iran, a country in which Garrusi and Baneshi (2017) note that an emphasis on research into body dissatisfaction has become more frequent; in Western cultures the research focus is on age groups or gender.

The above shows that body dissatisfaction is not just a health problem within the context of specific cultures, but that it is an issue that is possibly spreading globally, probably aided by an increase of technologies, media and social networks (Garrusi \& Baneshi, 2013).

There are differences in the instruments used by each research study to measure body dissatisfaction associated with the ideal of beauty. The studies analysed mainly used self-report tools, that is, instruments that are completed by the participants who respond to each item that has been asked to analyse body dissatisfaction through the assessment by oneself. This type of instrument is probably the most commonly used because it facilitates the assessment of a large number of people or samples, and can easily obtain a high volume of data in short periods of time. However, these tools are mainly focused on the female and/or adolescent population, which may make it difficult for males to understand or identify with the aspects being evaluated. 
Regarding the silhouette tools or visual scales, they only take into account models ranging from thin bodies to overweight bodies; they did not include silhouette models with a more developed muscle mass. This may have generated a bias in the investigations because it ignores gender differences and equates distortion with body image, which is what these types of tools, e.g., the FRS, mainly measure when analysing body dissatisfaction. In this sense, reviewing the scales and incorporating silhouettes and models with more muscular forms to them — reflecting and resembling the aesthetic body models that today's society promotes - would be of interest. Because the preparation and design of $18 \%$ of the research studies analysed used ad hoc questionnaires (whose purpose was to obtain information) and this type of tool results in collecting incomplete data, extending data collection beyond participants' perception to include the value they place on their body satisfaction and dissatisfaction might also be of interest. In addition, we should be more prudent when evaluating body dissatisfaction with tools aimed at distorting body image because they analyse different and nonsynonymous aspects.

However, these were not the only assessment methodologies used to measure body dissatisfaction. Forrester-Knauss and Stutz (2012) based their research on results obtained through a telephone survey and subsequently analysed this data quantitatively, which facilitates obtaining a high volume of data.

Regarding the main precipitating factors of body dissatisfaction associated with the ideal of beauty, the variables taken into account in each research study differed. There is consensus among the results obtained by current research and those concluded in previous literature (Alacid, López-Miñarro, Muyor, \& Vaquero-Cristobal, 2013), specifically those regarding the sociocultural influence which is one of the greatest, as it leads and pressures people to compare themselves to the aesthetic body models promoted by the media. Any discrepancies between the two seem to foster feelings of dissatisfaction with one's own body image and, as a result, increase the risk of wanting to modify or adjust that body image to these models (Esnaola et al., 2010).

Salcedo (2016) believes this is due to the frequent need to be socially accepted and, consequently, a desire to have an attractive body for others. In the case of males, as with females, having a body image that approximates the ideal of beauty is also associated with other positive characteristics such as success or health (Raich, 2000; Vaquero et al., 2014).

For these reasons, it seems that if one's body image is far from what is considered ideal, with the consequent body dissatisfaction, people seek to lose weight or modify their figure by executing certain risky eating behaviours (REB) as a means of reaching the thin weight favoured socially (Berengüí et al., 2016).

Physical exercise seems to be a moderating or mediating variable in regard to the development of body dissatisfaction; it predicts that people who more frequently practise any type of sport or physical activity have greater satisfaction with their body image (Arbinaga et al., 2011; González et al., 2013; Zaccagni et al., 2014), which is a finding that has previously been reported (Gómez \& Veiga, 2007). 
Finally, regarding age, we observed that the studies analysed mostly used populations of young adults aged between 18 and 25 . Only $18 \%$ of the studies analysed reported data from ages older than this range. A possible reason for this might be that both body dissatisfaction and the influence of different sociocultural factors are not so strong in older groups, although in some cases this decrease is only very small (Esnaola et al., 2010). On this basis, it seems that body dissatisfaction continues to increase until adulthood but, over time, this dissatisfaction is either maintained or decreases (Bucchianeri et al., 2013; Gillen \& Lefkowitz, 2012).

Based on the results found by the different research studies analysed, we can conclude that:

(1) The female population continues to show higher levels of body dissatisfaction compared to the male population, but the male population is also dissatisfied with their body image.

(2) Gender differences are that men want to lose weight while also wanting to increase their muscle mass; that is, females only seek to achieve a slim body, while males seek a thin body with muscle.

(3) Gender is a significant variable when considering the predisposition to develop body dissatisfaction associated with the ideal of beauty.

(4) Sociocultural variables and the desire to adjust to the aesthetic body models fostered by the media and advertising have the greatest influence on the development of body dissatisfaction.

(5) Physical activity acts as a moderating or mediating variable in the development of body dissatisfaction.

(6) Age influences the maintenance of body dissatisfaction, which seems to diminish over the years.

(7) Body dissatisfaction associated with the ideal of beauty is not a health problem associated with a specific culture, and it is possible that it is spreading throughout the world probably due to increasing technologies, media and social networks.

(8) Finally, there is a need to more seriously consider the variable of gender when designing research studies and interventions aimed at body dissatisfaction associated with the ideal of beauty.

One of the limitations of this work is that we selected only those studies whose full text was available for the development of our systematic review, and another is that we excluded publications in languages other than Spanish and English. Looking ahead to further, future studies in this area, increasing the number of sources and databases used to search for articles would be of interest, as would including studies carried out in other languages besides English and Spanish. In this way, we could increase the thoroughness of the data and, as a result, our knowledge of body dissatisfaction associated with the ideal of beauty. 
Another possible limitation of the review was the low number of publications found using a non-clinical adult population. The number of research studies obtained in total $(2,292)$, compared to the 18 studies finally used, shows that this section of the population has not been studied much, and focusing future research into such a population and not so much towards the clinical population of which we already have a greater scientific knowledge may be of interest for preventive purposes.

As future proposals, and because of the high number of people who show dissatisfaction with their body image, along with the risks to health that entails, such as possibly developing an eating disorder or compensatory behaviours, continuing to further investigate this area is necessary, while not ignoring the gender differences found between females and males regarding their body satisfaction/dissatisfaction.

This could be done by creating new tools or validating existing ones in the male and adult populations which can be used to assess gender differences in regard to their body dissatisfaction.

The combination of quantitative and qualitative study methodologies, such as, for example, interviews or discussion groups, could be another aspect to incorporate into future research. A combination of both methods would allow us to fully understand the testimonies and assessments given by people who suffer from body dissatisfaction associated with the ideal of beauty and enrich the data obtained so far.

On this basis, working towards the design of prevention and intervention programmes adjusted to gender differences as well as those that promote physical activity aimed at preventing the onset and development of body dissatisfaction should be explored.

As a conclusion, we found that there are increasing rates and levels of dissatisfaction that the general population manifests towards their own body image as there is a desire to adjust it to models of beauty that put health at risk. Because of this, and at a social level, it would be interesting to also direct attention to the media and, above all, to advertising, as these are among the main sources of sociocultural influence. One way to achieve this could be to develop campaigns aimed at promoting health and establishing healthy habits in society that favour well-being and personal acceptance. The main messages being transmitted and fostered in these cases would focus more on 'health' rather than 'beauty'. 


\section{Diferencias de género existentes en la población general en relación a la insatisfacción corporal asociada al ideal de belleza: una revisión sistemática}

La influencia que los medios de comunicación y la publicidad desempeñan en la transmisión de los modelos estéticos corporales ha favorecido que la imagen corporal haya ido cobrando con el tiempo una mayor repercusión. Sin embargo, estos modelos corporales que se nos presentan e incluso imponen, difieren en cuanto a género, ejerciendo una presión sociocultural distinta para mujeres y hombres (Oliveira \& Parra, 2014).

La imagen corporal se trata de un concepto multidimensional estudiado a lo largo de la historia y, cuya conceptualización, ha evolucionado desde principios del siglo XX especialmente (Baile, 2003; Rabito-Alcón \& Rodríguez-Molina, 2015, 2016).

Con una perspectiva integradora y mediante el compendio de las aportaciones de distintos autores, Raich (2004) define la imagen corporal como un constructo psicológico complejo que abarca tanto la percepción que la persona realiza de todo su cuerpo y cada una de sus partes, como el movimiento y límites de éste. La experiencia subjetiva de las actitudes, pensamientos, sentimientos y valoraciones que hace y siente de éste $\mathrm{y}$, en consecuencia, el modo de comportarse derivado de las cogniciones y sentimientos que experimenta. Por lo que, cuando una persona percibe que su imagen corporal no se ajusta o no se corresponde con el 'ideal de belleza' o con los 'modelos estéticos corporales prevalentes' tiene una mayor probabilidad de manifestar insatisfacción corporal (Rabito-Alcón \& Rodríguez-Molina, 2015).

La insatisfacción corporal hace referencia al malestar e insatisfacción que una persona puede llegar a sentir hacia su propio cuerpo. Bien sea por una sobreestimación, una infravaloración o una distorsión de sus proporciones corpo-rales de forma negativa en relación a partes específicas de todo su cuerpo o parte de él (Baile \& Velázquez-Castañeda, 2006; Sepúlveda, Botella, \& León, 2001). Mientras que Cash y Pruzinsky (2002) lo simplifican a las discrepancias de una persona entre su imagen corporal autopercibida y su imagen corporal ideal.

Además, la insatisfacción corporal se ha revelado como un factor de riesgo y buen predictor de los trastornos de la conducta alimentaria (TCA). Principalmente, en la población femenina y adolescente (Baile, Raich, \& Garrido, 2003; Gómez \& Veiga, 2007; García, \& Martínez, 2013; Rodríguez-Ruiz et al., 2013; Trujano et al., 2010). No obstante, las investigaciones realizadas en la última década revelan un cambio respecto a la tendencia de que sea esta población la más afectada, habiendo obtenido resultados que demuestran que la población masculina también manifiesta sentirse insatisfecha con su imagen corporal cuando ésta se aleja del ideal masculino 
imperante (Magallares, 2016; Vázquez, López-Aguilar, Álvarez-Rayón, Manzilla, \& Oliva, 2016).

Esnaola, Rodríguez, y Goñi (2010) encuentran que cuanto más alto son los niveles de presión percibidos por las personas en relación a una imagen corporal idealizada, independientemente de que sean mujeres u hombres, mayor es la preocupación por la imagen corporal. En consecuencia, el riesgo de aparición de estrategias dirigidas a obtener un cambio corporal que, en ocasiones, pueden precipitar a la persona a poner en riesgo su salud.

Podemos decir entonces que, la insatisfacción corporal, se trata de una variable con consecuencias individuales y sociales relevantes. En cuya formación intervienen, con distinto peso, factores de carácter: individual, social y cultural. Entre los cuales, cobran especial relevancia 'los modelos estéticos corporales' (Amaya, Álvarez, \& Mancilla, 2010; Bully, Elosua, \& López-Jáuregui, 2012).

Cuando hablamos del ideal de belleza actual, hacemos referencia según Espósito (2015) a aquellos estereotipos de 'cuerpo ideal' construidos de manera social y promovidos de forma mediática, utilizados por los medios de comunicación y la publicidad como canon de 'cuerpos bellos' o 'cuerpos que se deben aspirarse a tener'. Dichos modelos, que se impondrían como los únicos válidos, estarían acentuando la insatisfacción con el propio cuerpo e incrementando los niveles de insatisfacción con la imagen corporal.

Según Cruz y Maganto (2008) estos modelos corporales exaltan para la mujer, cuerpos extremadamente delgados y con formas poco redondeadas. Cuerpos andróginos y angulosos donde las características sexuales aparecen difuminadas para el género femenino. Mientras que, para el hombre, el ideal de belleza va dirigido a cuerpos atléticos, con pectorales y abdominales desarrollados, espaldas anchas y cinturas estrechas.

Como podemos observar, el género juega un papel fundamental en la manera que hombres y mujeres perciben, sienten o valoran, a nivel general, su cuerpo e imagen corporal. Otorgando, para el género femenino, una mayor importancia a: la belleza física, la apariencia personal y el atractivo sexual. En cambio, para el género masculino, la imagen estaría establecida en otro tipo de habilidades más relacionadas con: la fortaleza y la virilidad (Esnaola, 2005; Raich, 2000; Vaquero et al., 2014).

Investigaciones anteriores como las que se mencionan a continuación, encontraron que a pesar de que la presión social a favor de la delgadez ha sido mayor en las mujeres, se trata de un fenómeno con evidencia en los hombres. En este caso, Trejo, Castro, Facio, Mollinedo, y Valdez (2010) destacaron que, para el género femenino, la sociedad y los medios promueven una imagen delgada, por la cual, nace el deseo de las mujeres de querer adelgazar y bajar de peso para ajustarse al 'ideal de belleza delgado'. Mientras que, para los hombres, los medios de comunicación proyectan 'modelos musculosos' que llevan a la población masculina a querer aumentar su masa muscular. En esta misma línea, Trujano et al. (2010) encontraron evidencias de que los estereotipos actuales de 'delgadez extrema' continúan impactando más en el género femenino a diferencia del masculino, quien buscaría estar delgado, pero, al mismo tiempo, musculado.

Con motivo de las diferencias de género asociadas al ideal de belleza encontradas por investigaciones anteriores, Amaya et al. (2010) desarrollaron 
una revisión en el periodo de 2000 a 2009 con población adolescente donde concluyen que la insatisfacción corporal difiere en cuanto al género, especialmente, en la adolescencia. Estos autores, dejan entrever que, la insatisfacción con el cuerpo, también puede tener su origen en el deseo de mayor peso y/o tono muscular, independientemente del género. Atendiendo a estos resultados, señalaron la necesidad de continuar examinando las diferencias de género y tipos de insatisfacción corporal. En una segunda revisión, dirigida a conocer las variables precursoras de la insatisfacción corporal en población infantil y adolescente en el periodo comprendido entre 1990 y 2011, ambos géneros mostraron altos niveles de insatisfacción corporal además de preocupación por el peso y la forma. Las cuales, de acuerdo al género, se presentaban de forma diferente para mujeres y hombres (Mancilla, Vázquez, Mancilla, Amaya, \& Álvarez, 2012).

Ante la diversidad de los estudios y revisiones que demostraron las diferencias existentes respecto al género y la edad en la insatisfacción corporal asociada al ideal de belleza y ante la falta de datos encontrados con población adulta no clínica, se elaboró una revisión sistemática de los trabajos sobre el tema pu-blicados entre 2010 y 2018 con el propósito de conocer el estado actual de las diferencias por géneros en relación a la insatisfacción corporal asociada al ideal de belleza en población general mayor de 18 años.

\section{Método}

\section{Muestra y selección de los artículos}

En la Figura 1 se describe el procedimiento de búsqueda desarrollado de manera sistemática de las publicaciones sobre insatisfacción corporal asociada al ideal de belleza durante el periodo comprendido entre 2010 a julio de 2018 a través de las bases de datos: MeSH/ PubMed, Dialnet y DOAJ. Introduciendo como palabras claves los términos indexados en MeSH/PubMed: 'Body Image', 'Body Dysmorphic Disorders', 'Personal Satisfaction', 'Sex Distribution', 'Beauty', en sus diferentes combinaciones.

La selección de los artículos se llevó a cabo aplicando una serie de criterios de inclusión y exclusión que se detallan en la Tabla 1.

\section{Resultados}

\section{Artículos seleccionados}

El total de artículos encontrados al introducir los términos indexados fue de 2,292. Los cuales, fueron filtrados en las bases de datos por: año de publicación entre 2010-18, muestras seleccionadas de hombres y mujeres mayores de 18 años y disponibles a texto completo, reduciéndose el número de publicaciones a 117. La búsqueda de artículos fue actualizada hasta el 15 de julio de 2018 .

Tras la lectura exhaustiva de los estudios filtrados por las bases de datos, un total de 18 publicaciones, mostradas en la Tabla 2, fueron seleccionadas por cumplir todos los criterios de inclusión y ninguno de exclusión. 


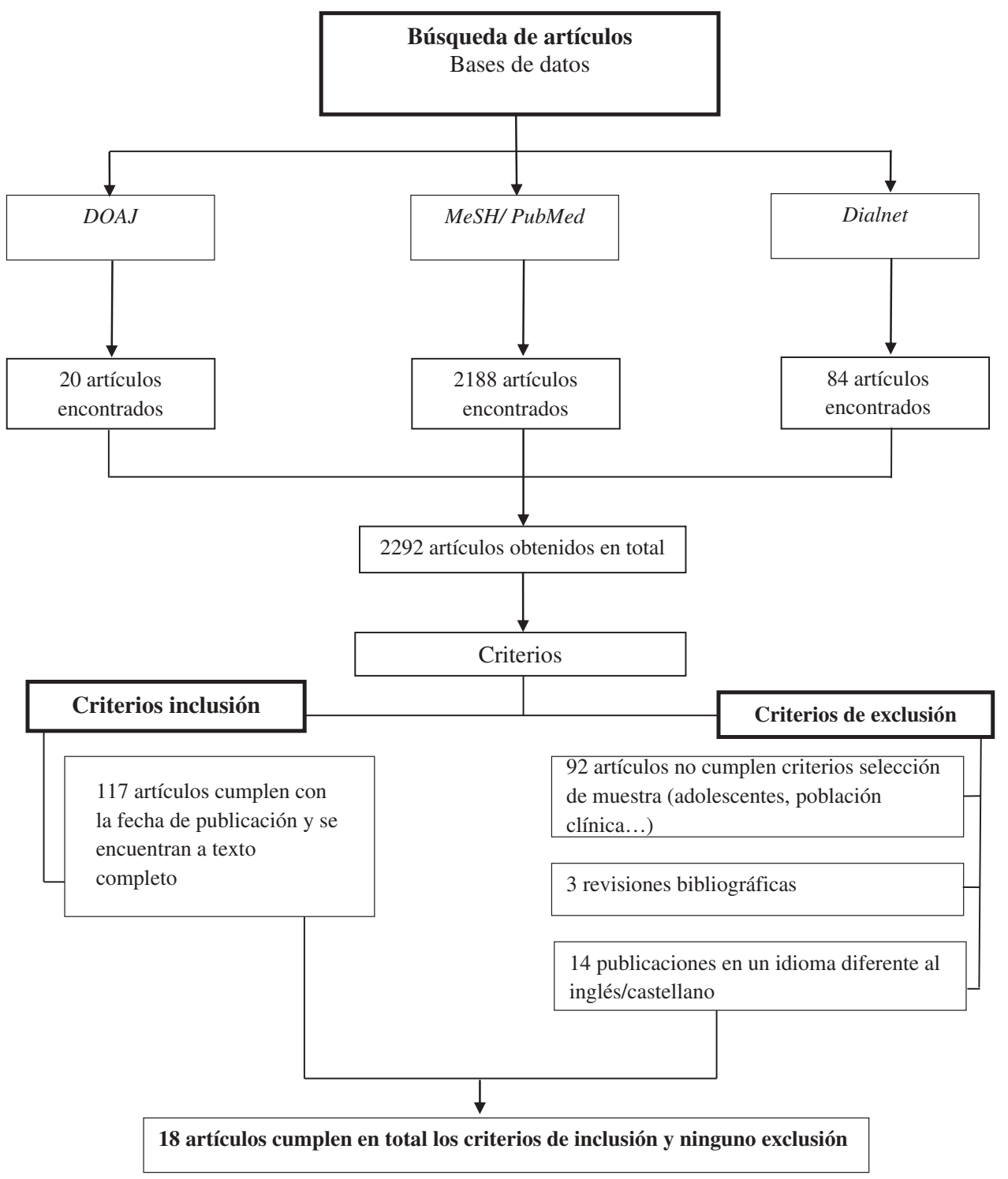

Figura 1. Representación de los pasos desarrollados de manera sistemática para la selección de los artículos sobre los que ha versado la revisión en base a los criterios de inclusión/exclusión.

\section{Análisis de los artículos}

Año de publicación

Para el periodo delimitado de búsqueda de artículos con carácter científico comprendió desde el año 2010 hasta mediados de julio de 2018, se observó un aumento progresivo a lo largo de los años en el número de publicaciones. Siendo 2013 (Bucchianeri, Arikian, Hannan, Eisenberg, \& Neumark-Sztainer, 2013; Garrusi \& Baneshi, 2013; González et al., 2013; Siegling \& Delaney, 2013) y 
Tabla 1. Criterios de inclusión/exclusión.

\begin{tabular}{|c|c|}
\hline Criterios de inclusión & Criterios de exclusión \\
\hline $\begin{array}{l}\text { (1) Todos aquellos artículos que } \\
\text { tuvieran en cuenta la relación } \\
\text { entre insatisfacción corporal, } \\
\text { género e ideal de belleza en } \\
\text { población general. } \\
\text { (2) Publicados entre } 2010 \text { y julio de } \\
2018 \text {. } \\
\text { (3) Redactados en castellano o } \\
\text { inglés. } \\
\text { (4) De carácter cuantitativo. } \\
\text { (5) Muestras compuestas por } \\
\text { mujeres y hombres mayores de } \\
18 \text { años. } \\
\text { (6) Disponibles a texto completo. }\end{array}$ & $\begin{array}{l}\text { (1) Las investigaciones y/o estudios } \\
\text { desarrollados con población o } \\
\text { grupos clínicos. } \\
\text { (2) Muestras conformadas por un } \\
\text { único género (hombres o } \\
\text { mujeres). } \\
\text { (3) Redactados en un idioma difer- } \\
\text { ente al castellano o al inglés. } \\
\text { (4) No disponible a texto completo. } \\
\text { (5) Revisiones y/o estudios de } \\
\text { carácter cualitativo. }\end{array}$ \\
\hline
\end{tabular}

2016 (Berengüí, Castejón, \& Torregrosa, 2016; Chng \& Fassnacht, 2016; Salcedo, 2016; Zueck, Pinto, Pando, \& Guedea, 2016) los años con mayor número de publicaciones encontradas, con cuatro artículos por año. Seguidamente, 2015 con tres publicaciones (Ejike, 2015; Mintem, Gigante, \& Horta, 2015; Salvador, García-Gálvez, \& De La Fuente, 2015), 2012 con dos (Forrester-Knauss \& Stutz, 2012; Gillen \& Lefkowitz, 2012) y, 2010 (Esnaola et al., 2010), 2011 (Arbinaga, García, Vázquez, Joaquín, \& Pazos, 2011), 2014 (Zaccagni, Masotti, Donati, Mazzoni, \& Gualdi-Russo, 2014), 2017 (Garrusi \& Baneshi, 2017) y 2018 (Salgado \& Álvarez, 2018), con un único artículo respectivamente.

\section{Revistas}

Las revistas que contaron con un mayor número de publicaciones sobre las diferencias de género en la insatisfacción corporal asociada al ideal de belleza, fueron: Body Image con el $16.67 \%$ de los estudios seleccionados (Bucchianeri et al., 2013; Chng \& Fassnacht, 2016; Gillen \& Lefkowitz, 2012) y BMC Public Health, con el 11.11\% (Forrester-Knauss \& Stutz, 2012; Mintem et al., 2015). El resto de artículos, fueron publicados por revistas diferentes.

\section{Objetivos}

La mayor parte de las investigaciones, como puede verse en la Tabla 2, tuvieron como objetivo global conocer y evaluar las diferencias de género existentes en la insatisfacción corporal asociada al ideal de belleza. Además, otras variables se relacionaron con la insatisfacción corporal, como: el índice de 
Tabla 2. Artículos seleccionados sobre la insatisfacción corporal en población general entre 2010-18.

\begin{tabular}{|c|c|c|}
\hline Estudio & Objetivo & Resultados \\
\hline Esnaola et al. (2010) & $\begin{array}{l}\text { Examinar la relación del } \\
\text { género y la edad entre la } \\
\text { imagen corporal y presiones } \\
\text { socioculturales percibidas } \\
\text { con respecto a los ideales del } \\
\text { cuerpo desde la adolescencia } \\
\text { hasta la vejez. }\end{array}$ & $\begin{array}{l}\text { La variable de género sería más } \\
\text { significativa que la edad } \\
\text { para explicar las diferencias } \\
\text { en la insatisfacción corporal. } \\
\text { Manifestando los hombres } \\
\text { menos insatisfacción } \\
\text { corporal y percibiéndose } \\
\text { menos influenciados por los } \\
\text { modelos estéticos corporales } \\
\text { que las mujeres. }\end{array}$ \\
\hline $\begin{array}{l}\text { Arbinaga, García, } \\
\text { Vázquez, Joaquín, y } \\
\text { Pazos (2011) }\end{array}$ & $\begin{array}{l}\text { Aportar datos sobre las } \\
\text { actitudes de los } \\
\text { universitarios y las } \\
\text { relaciones que pudieran } \\
\text { establecerse con los hábitos } \\
\text { alimenticios y la satisfacción } \\
\text { con la imagen corporal. }\end{array}$ & $\begin{array}{l}\text { Las mujeres muestran una } \\
\text { mayor insatisfacción } \\
\text { corporal en contraposición a } \\
\text { los hombres, mostrándose } \\
\text { más satisfechos con su } \\
\text { imagen corporal aquellos } \\
\text { que practican mayor } \\
\text { volumen de deporte. }\end{array}$ \\
\hline $\begin{array}{l}\text { Forrester-Knauss y } \\
\text { Stutz (2012) }\end{array}$ & $\begin{array}{l}\text { Examinar las tasas de } \\
\text { prevalencia de la } \\
\text { insatisfacción con el peso, la } \\
\text { alimentación desordenada y } \\
\text { factores sociodemográficos } \\
\text { en hombres y mujeres. }\end{array}$ & $\begin{array}{l}\text { Más de la mitad de las mujeres } \\
\text { y hombres deseaban cambiar } \\
\text { su peso. En su mayoría, } \\
\text { queriendo perder peso por } \\
\text { parte de las mujeres y } \\
\text { aumentando masa muscular } \\
\text { los hombres. }\end{array}$ \\
\hline $\begin{array}{l}\text { Gillen y Lefkowitz } \\
\text { (2012) }\end{array}$ & $\begin{array}{l}\text { Examinar si se producen } \\
\text { cambios en la imagen } \\
\text { corporal durante la primera } \\
\text { etapa de la universidad y si } \\
\text { existen diferencias de género } \\
\text { o grupo racial/etnia. }\end{array}$ & $\begin{array}{l}\text { Los hombres universitarios } \\
\text { estaban más satisfechos con } \\
\text { su apariencia que las } \\
\text { mujeres. Siendo el efecto de } \\
\text { tiempo únicamente } \\
\text { significativo para las } \\
\text { universitarias, quienes se } \\
\text { volvieron cada vez más } \\
\text { satisfechas con su aparición } \\
\text { en el tiempo. }\end{array}$ \\
\hline $\begin{array}{l}\text { Bucchianeri et al. } \\
\text { (2013) }\end{array}$ & $\begin{array}{l}\text { Abordar la evidencia sobre el } \\
\text { curso de la insatisfacción } \\
\text { corporal a través de los } \\
\text { períodos de transición entre } \\
\text { la adolescencia a la edad } \\
\text { adulta. }\end{array}$ & $\begin{array}{l}\text { Los participantes se volvieron } \\
\text { progresivamente más } \\
\text { insatisfechos con sus } \\
\text { cuerpos durante un período } \\
\text { de } 10 \text { años. }\end{array}$ \\
\hline $\begin{array}{l}\text { Garrusi y Baneshi } \\
\text { (2013) }\end{array}$ & $\begin{array}{l}\text { Explorar la prevalencia de los } \\
\text { trastornos alimentarios y sus } \\
\text { factores de riesgo en la } \\
\text { población iraní. }\end{array}$ & $\begin{array}{l}\text { La insatisfacción corporal fue } \\
\text { considerada como un } \\
\text { problema central en el } \\
\text { desarrollo de los trastornos } \\
\text { alimentarios pero su efecto } \\
\text { no fue obvio en las mujeres. }\end{array}$ \\
\hline
\end{tabular}


Tabla 2. (Continuación).

\begin{tabular}{|c|c|c|}
\hline Estudio & Objetivo & Resultados \\
\hline $\begin{array}{l}\text { González, García y } \\
\text { Martínez (2013) }\end{array}$ & $\begin{array}{l}\text { Evaluar los comportamientos } \\
\text { alimentarios y la imagen } \\
\text { corporal en población } \\
\text { universitaria. }\end{array}$ & $\begin{array}{l}\text { Las mujeres tenían un nivel de } \\
\text { insatisfacción corporal } \\
\text { mayor que los hombres, } \\
\text { mostrando deseo por querer } \\
\text { pesar menos y mostrándose } \\
\text { más preocupadas por su } \\
\text { imagen corporal en relación } \\
\text { a los hombres. }\end{array}$ \\
\hline $\begin{array}{l}\text { Siegling y Delaney } \\
\text { (2013) }\end{array}$ & $\begin{array}{l}\text { Examinar el papel del } \\
\text { perfeccionismo cognitivo y } \\
\text { los esquemas de género en } \\
\text { relación a la importancia con } \\
\text { la imagen corporal (BII). }\end{array}$ & $\begin{array}{l}\text { Evidencia de que la BII y la } \\
\text { satisfacción corporal están } \\
\text { asociadas como una función } \\
\text { del perfeccionismo. Así } \\
\text { como la interacción del sexo } \\
\text { y la esquemática de género } \\
\text { con la BII. }\end{array}$ \\
\hline $\begin{array}{l}\text { Zaccagni, Masotti, } \\
\text { Donati, Mazzoni, y } \\
\text { Gualdi-Russo (2014) }\end{array}$ & $\begin{array}{l}\text { Examinar la percepción de la } \\
\text { imagen corporal, el grado de } \\
\text { insatisfacción y la } \\
\text { inconsistencia de la } \\
\text { percepción del peso en una } \\
\text { muestra de universitarios. }\end{array}$ & $\begin{array}{l}\text { La insatisfacción con la imagen } \\
\text { corporal afecta a ambos } \\
\text { sexos y está influenciada } \\
\text { tanto por la cultura como por } \\
\text { la sociedad favoreciendo a } \\
\text { menudo modelos cercanos a } \\
\text { los de las personas que } \\
\text { padecen anorexia. }\end{array}$ \\
\hline Ejike (2015) & $\begin{array}{l}\text { Investigar la prevalencia de } \\
\text { preferencia de peso e } \\
\text { insatisfacción con la imagen } \\
\text { corporal entre los nigerianos. }\end{array}$ & $\begin{array}{l}\text { Más de la mitad de la } \\
\text { población indicó estar } \\
\text { insatisfecha con su imagen } \\
\text { corporal. }\end{array}$ \\
\hline $\begin{array}{l}\text { Garrusi y Baneshi } \\
\text { (2017) }\end{array}$ & $\begin{array}{l}\text { Evaluar la insatisfacción } \\
\text { general del cuerpo e } \\
\text { identificar los factores que } \\
\text { podrían afectar la } \\
\text { insatisfacción corporal en los } \\
\text { iraníes. }\end{array}$ & $\begin{array}{l}\text { Alrededor de dos tercios de los } \\
\text { participantes tenían algún } \\
\text { grado de insatisfacción } \\
\text { corporal, extrayéndose una } \\
\text { correlación positiva entre el } \\
\text { IMC y la insatisfacción } \\
\text { corporal, lo que sugiere que } \\
\text { un aumento en el IMC se } \\
\text { asocia con un aumento en la } \\
\text { insatisfacción corporal. }\end{array}$ \\
\hline $\begin{array}{l}\text { Salgado y Álvarez } \\
\text { (2018) }\end{array}$ & $\begin{array}{l}\text { Comparar entre hombres y } \\
\text { mujeres, aspectos } \\
\text { relacionados con: imagen } \\
\text { corporal, IMC, (in) } \\
\text { satisfacción con la imagen } \\
\text { corporal, y conocer la } \\
\text { manera en la que se ven } \\
\text { ellos mismos (Yo real), } \\
\text { cómo les gustaría verse (Yo } \\
\text { ideal) y cómo ven a sus } \\
\text { compañeros. }\end{array}$ & $\begin{array}{l}\text { Mayor prevalencia de } \\
\text { sobrepeso/obesidad en } \\
\text { hombres y una mayor } \\
\text { proporción de mujeres a } \\
\text { quienes les preocupa } \\
\text { engordar y desean cambiar } \\
\text { alguna parte de su cuerpo, } \\
\text { reportando más insatisfacción } \\
\text { con su imagen corporal por el } \\
\text { deseo de bajar de peso, } \\
\text { independientemente de su } \\
\text { IMC. }\end{array}$ \\
\hline
\end{tabular}


masa corporal (IMC) y la percepción del peso (Bucchianeri et al., 2013; Chng \& Fassnacht, 2016; Ejike, 2015; Forrester-Knauss \& Stutz, 2012; Garrusi \& Baneshi, 2017; Mintem et al., 2015; Salcedo, 2016; Salgado \& Álvarez, 2018; Siegling \& Delaney, 2013), las presiones socioculturales (Esnaola et al., 2010; Gillen \& Lefkowitz, 2012), los hábitos alimentarios (Arbinaga et al., 2011), el riesgo de TCA (Garrusi \& Baneshi, 2013), los factores cognitivos como el perfeccionismo (Siegling \& Delaney, 2013), las conductas de riesgo y/o compensatorias (Berengüí et al., 2016), el desarrollo y práctica de actividad física (Arbinaga et al., 2011; González et al., 2013; Zaccagni et al., 2014) o la influencia de los comentarios parentales (Chng \& Fassnacht, 2016) en el desarrollo de insatisfacción corporal.

\section{Escenario}

Casi el $80 \%$ de las publicaciones procedieron de países occidentales, entre ellos: 27.78\% de España (Arbinaga et al., 2011; Berengüí et al., 2016; Esnaola et al., 2010; González et al., 2013; Salvador et al., 2015), 11.11\% de EE. UU (Bucchianeri et al., 2013; Gillen \& Lefkowitz, 2012) y, con un 5.56\% respectivamente: Suecia (ForresterKnauss \& Stutz, 2012), Canadá (Siegling \& Delaney, 2013), Italia (Zaccagni et al., 2014). De los países de Sudamérica un $11.11 \%$ de las publicaciones procedieron de México (Salgado \& Álvarez, 2018; Zueck et al., 2016) y otro 11.11\% de Brasil (Mintem et al., 2015) y Colombia (Salcedo, 2016). El 16.67\% restantes de las publicaciones, tuvieron su origen en oriente: $11.11 \%$ en Irán (Garrusi \& Baneshi, 2013, 2017) y 5.56\% en Singapur (Chng \& Fassnacht, 2016).

De todas ellas, el $50 \%$ de las investigaciones se desarrollaron en entornos universitarios (Arbinaga et al., 2011; Berengüí et al., 2016; Ejike, 2015; Gillen \& Lefkowitz, 2012; González et al., 2013; Salcedo, 2016; Salvador et al., 2015; Zaccagni et al., 2014; Zueck et al., 2016).

\section{Muestra}

El tamaño de las muestras, descritas en la Tabla 3, se encontró entre 89 (González et al., 2013) y 18,156 participantes (Forrester-Knauss \& Stutz, 2012). Siendo la proporción de mujeres significativamente mayor en número que la de hombres a excepción de cuatro publicaciones (Ejike, 2015; Garrusi \& Baneshi, 2017; Salgado \& Álvarez, 2018; Zaccagni et al., 2014).

Respecto a la edad de los participantes, un $16.67 \%$ de las investigaciones tomaron varios grupos de edad entre la adolescencia a la edad adulta (Bucchianeri et al., 2013; Esnaola et al., 2010; Garrusi \& Baneshi, 2017). De los cuales, solo se hizo uso de los resultados de aquellos grupos mayores de 18 años. El resto de investigaciones, fueron realizadas a partir de un único grupo cuyos participantes tenía la mayoría de edad.

De los estudios analizados: el $66.67 \%$ indicaron la edad media de la muestra de manera total (Berengüí et al., 2016; Bucchianeri et al., 2013; Chng \& Fassnacht, 2016; Ejike, 2015; Esnaola et al., 2010; Garrusi \& Baneshi, 2013, 
Tabla 3. Distribución por género y edad de las muestras estudiadas por los artículos seleccionados.

\begin{tabular}{|c|c|c|c|c|}
\hline \multirow[b]{2}{*}{ Estudio } & \multicolumn{3}{|c|}{ Muestra } & \multirow[b]{2}{*}{ Descripción (Edad) } \\
\hline & Mujeres & Hombres & Total & \\
\hline Esnaola et al. (2010) & 702 & 557 & 1,259 & $\begin{array}{l}\text { Cuatro grupos de edad: } 627 \\
\text { adolescentes (12-18 años; } \\
M=15.33), 272 \text { adultos } \\
\text { jóvenes (19-30 años; } \\
M=22.50), 248 \text { adultos } \\
\text { medianos (31-49 años; } \\
M=39.88) \text { y } 112 \text { mayores de } \\
55 \text { años }(M=60.36)\end{array}$ \\
\hline Arbinaga et al. (2011) & 105 & 55 & 160 & $\begin{array}{l}M=20.76 \text { años (Mujeres, } \\
M=21.81 ; \text { Hombres } \\
M=20.23 \text { ) }\end{array}$ \\
\hline $\begin{array}{l}\text { Forrester-Knauss y Stutz } \\
\text { (2012) }\end{array}$ & 9,516 & 7,570 & 18,156 & $\begin{array}{c}M=50.7 \text { años (Mujeres, } \\
\quad M=51.56 ; \text { Hombres } \\
M=49.60)\end{array}$ \\
\hline Gillen y Lefkowitz (2012) & 210 & 180 & 390 & $\begin{array}{c}M=19.50 \text { años (Mujeres, } \\
M=19.44 ; \text { Hombres } \\
M=19.57)\end{array}$ \\
\hline $\begin{array}{l}\text { Bucchianeri, Arikian, } \\
\text { Hannan, Eisenberg, y } \\
\text { Neumark-Sztainer } \\
\text { (2013) }\end{array}$ & 1,083 & 819 & 1,902 & $M=23.2$ años \\
\hline Garrusi y Baneshi (2013) & 640 & 541 & 1,181 & $M=31.06$ años \\
\hline González et al. (2013) & 64 & 25 & 89 & $\begin{array}{c}M=23.8 \text { años (Mujeres, } \\
M=25.12 ; \text { Hombres } \\
M=23.36 \text { ) }\end{array}$ \\
\hline Siegling y Delaney (2013) & 110 & 30 & 141 & $M=20.18$ años \\
\hline Zaccagni et al. (2014) & 354 & 380 & 734 & $\begin{array}{l}\text { Mujeres, } M=21.5 \text {; Hombres, } \\
\quad M=22.1\end{array}$ \\
\hline Ejike (2015) & 2,000 & 380 & 2,380 & $M=21.7$ años \\
\hline $\begin{array}{l}\text { Mintem, Gigante, y Horta } \\
\text { (2015) }\end{array}$ & 1,739 & 1,963 & 3,702 & $M=22.7$ años \\
\hline $\begin{array}{l}\text { Salvador, García-Gálvez, y } \\
\text { de la Fuente (2015) }\end{array}$ & 505 & 235 & 740 & $\begin{array}{l}\text { Tres grupos de edad: } 453 \text { muy } \\
\text { jóvenes (18-20 años), } 258 \\
\text { jóvenes ( } 21-30 \text { años) y } \\
\text { adultos jóvenes (31-51 años): } \\
M=21.15 \text { años }\end{array}$ \\
\hline $\begin{array}{l}\text { Berengüí, Castejón, y } \\
\text { Torregrosa (2016) }\end{array}$ & 148 & 116 & 264 & $M=22.62$ años \\
\hline Chng y Fassnacht (2016) & 265 & 118 & 383 & $M=21.2$ años \\
\hline Salcedo (2016) & 152 & 48 & 200 & Entre 18 y 25 años \\
\hline $\begin{array}{l}\text { Zueck, Pinto, Pando, y } \\
\text { Guedea (2016) }\end{array}$ & 871 & 706 & 1,577 & $M=20.64$ años \\
\hline Garrusi y Baneshi (2017) & 635 & 549 & 2,014 & $\begin{array}{l}\text { Tres grupos de edad: } 187(<20 \\
\text { años), } 783 \text { ( } 20-40 \text { años }), 213 \\
\text { ( }>40 \text { años); }(M=31.06)\end{array}$ \\
\hline Salgado y Álvarez (2018) & 168 & 132 & 300 & $M=20.53$ años \\
\hline Total & 19,264 & 14,404 & 35,572 & \\
\hline
\end{tabular}

Nota: $M=$ media de edad. Descripción de las muestras seleccionadas por los artículos analizados, ordenados por año de publicación. 
2017; Mintem et al., 2015; Salgado \& Álvarez, 2018; Salvador et al., 2015; Siegling \& Delaney, 2013; Zueck et al., 2016) siendo la más alta 50.7 años (Forrester-Knauss \& Stutz, 2012). Un 22.22\%, además de los datos relativos a la media de edad total de la muestra, proporcionaron también datos de la media de cada grupo en base al género, diferenciando de este modo un grupo de mujeres y otro de hombre (Arbinaga et al., 2011; Forrester-Knauss \& Stutz, 2012; Gillen \& Lefkowitz, 2012; González et al., 2013).

El 11.11\% restante, solo indicaron el rango de edad en el que los participantes fueron seleccionados (Garrusi \& Baneshi, 2013; Salcedo, 2016).

\section{Instrumentos}

En la Tabla 4 se pueden observar las herramientas de evaluación utilizadas por las diferentes investigaciones analizadas para evaluar y medir la insatisfacción corporal asociada al ideal de belleza.

En este sentido, a pesar de que existe una gran diversidad de formas de evaluar la insatisfacción corporal, las herramientas más utilizadas por los artículos seleccionados fueron: Body Shape Questionnaire (BSQ) de Cooper, Taylor, Cooper, y Fairburn (1987) por un 22.22\% de las publicaciones seleccionadas (Arbinaga et al., 2011; Bucchianeri et al., 2013; González et al., 2013; Salcedo, 2016), Figure Rating Scale (FRS) de Stundarkd, Sorensen, y Schulsinger (1983) por 22.22\% de los artículos (Ejike, 2015; Garrusi \& Baneshi, 2013, 2017; Mintem et al., 2015) y Eating Disorder Inventory (EDI) de Garner, D. M (1990) en las versiones revisadas de 1990 (EDI-2), traducida al castellano (Corral et al., 1998) (Esnaola et al., 2010) y, la versión revisada en 2004 (EDI-3), traducida por Elosua, López-Jáuregui, y Sánchez-Sánchez (2010) (Berengüí et al., 2016).

El 50\% restante de las investigaciones seleccionadas, utilizaron herramientas de auto-reporte o auto-informe (Chng \& Fassnacht, 2016; Gillen \& Lefkowitz, 2012; Siegling \& Delaney, 2013), escalas visuales (González et al., 2013; Salgado \& Álvarez, 2018; Zaccagni et al., 2014) o cuestionarios ad hoc elaborados de manera concreta para evaluar la insatisfacción corporal asociada al ideal de belleza mediante la elaboración de preguntas cerradas con varias opciones de respuesta (Berengüí et al., 2016; Forrester-Knauss \& Stutz, 2012; Salvador et al., 2015).

Además de la insatisfacción corporal, los estudios seleccionados estudiaron la interacción de ésta con otras variables. En el 44.44\% de las investigaciones seleccionadas, tomaron datos del IMC de la persona mediante la medida del peso y la altura o de manera autoinformada (Bucchianeri et al., 2013; Ejike, 2015; Forrester-Knauss \& Stutz, 2012; Garrusi \& Baneshi, 2013; Mintem et al., 2015; Salcedo, 2016; Salgado \& Álvarez, 2018; Zaccagni et al., 2014), en otros trabajos se incluyeron variables como la autoestima (Garrusi \& Baneshi, 2013; Salvador et al., 2015), la actitud hacia la comida o hábitos alimentarios (Arbinaga et al., 2011;Chng \& Fassnacht, 2016; Forrester-Knauss \& Stutz, 2012; González et al., 2013), la práctica de actividad física (Arbinaga et al., 2011; Zaccagni et al., 2014; Zueck et al., 2016) la relación entre el 'Yo real' y el 'Yo ideal' (Salgado \& Álvarez, 2018). 


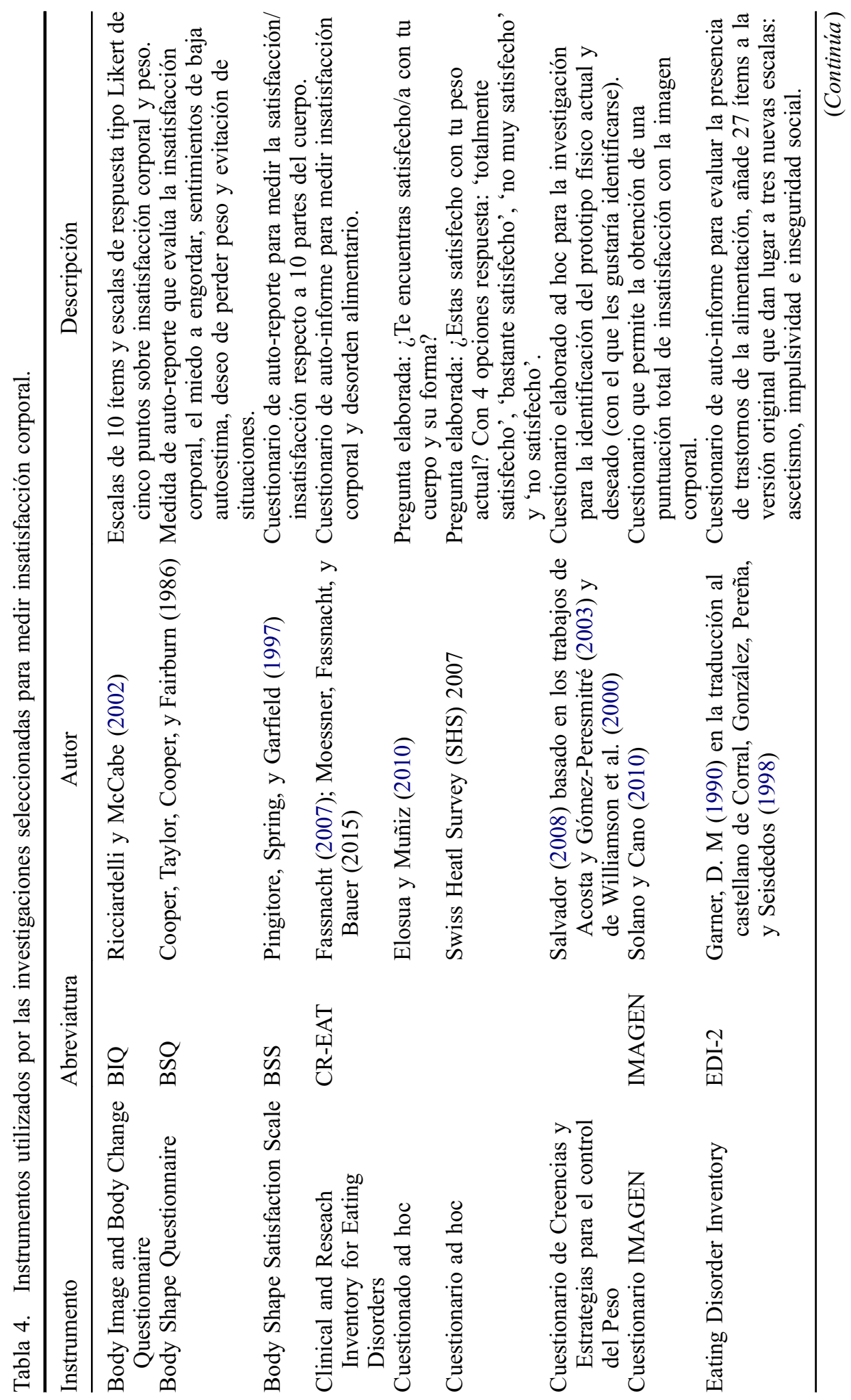




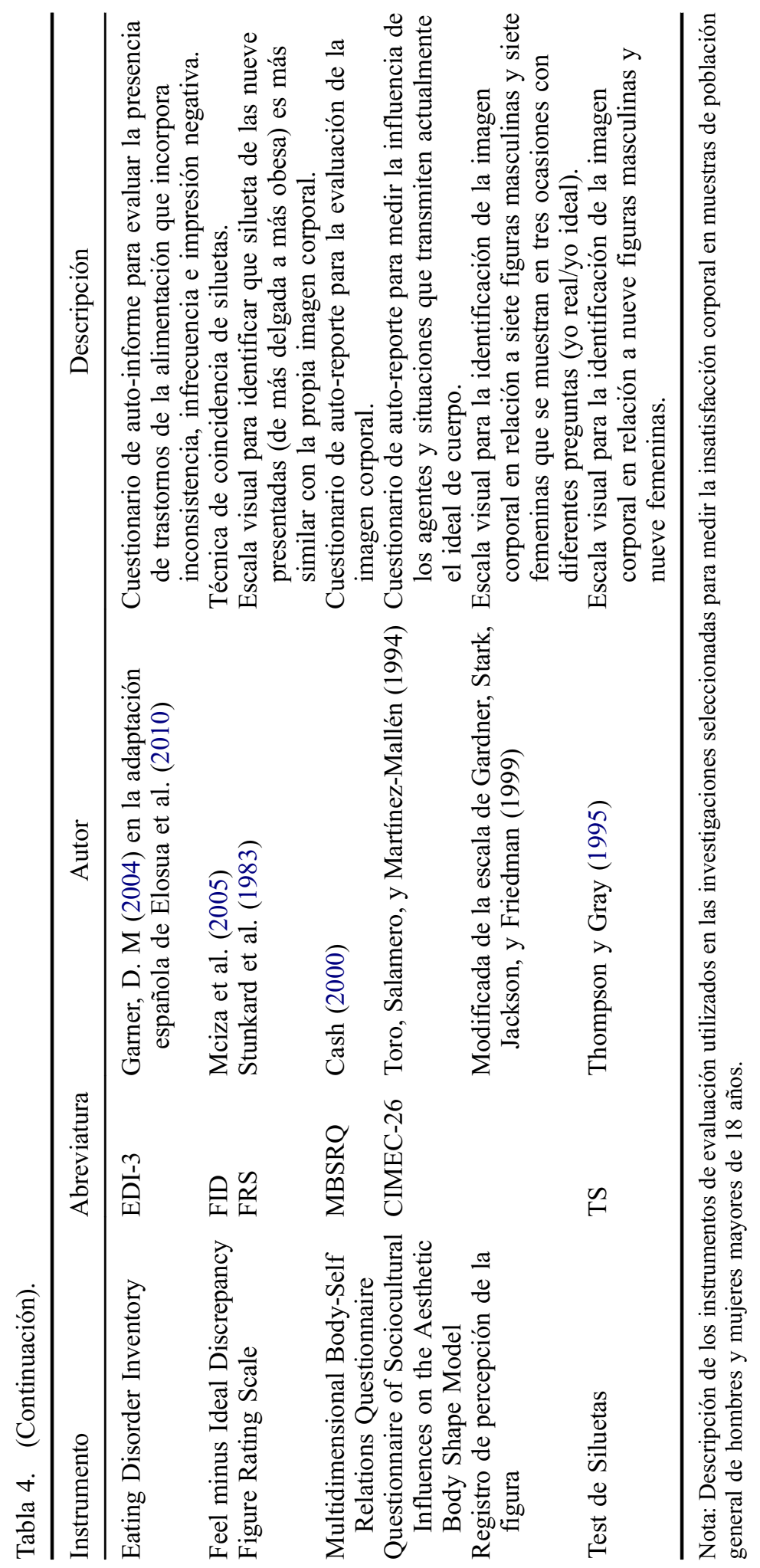




\section{Hallazgos de investigación}

Con el objetivo de examinar las tasas de prevalencia de la insatisfacción corporal asociada al ideal de belleza en mujeres y hombres, los resultados obtenidos por el $72.22 \%$ de las investigaciones analizadas, mostraron que existen diferencias significativas en cuanto a la insatisfacción corporal de hombres y mujeres respecto a su imagen corporal asociada el ideal de belleza: reportando la población femenina una mayor insatisfacción hacia su imagen corporal y peso que los hombres (Arbinaga et al., 2011; Chng \& Fassnacht, 2016; Ejike, 2015; Esnaola et al., 2010; ForresterKnauss \& Stutz, 2012; Garrusi \& Baneshi, 2017; Gillen \& Lefkowitz, 2012; González et al., 2013; Mintem et al., 2015; Salgado \& Álvarez, 2018; Salvador et al., 2015; Zaccagni et al., 2014; Zueck et al., 2016). En contraposición, Garrusi and Baneshi (2013) no encontraron diferencias significativas por géneros.

Sobre la relación entre la edad de los sujetos y el nivel de insatisfacción corporal, los estudios analizados reportaron que las mujeres y hombres se sintieron más insatisfechos durante la transición entre la adolescencia a la vida adulta y que, a medida que pasa el tiempo, la insatisfacción corporal comienza a decrecer con el aumento de edad hasta estabilizarse (Berengüí et al., 2016; Bucchianeri et al., 2013; Salcedo, 2016; Zaccagni et al., 2014).

Con el objetivo de examinar si existen diferencias de género en relación a la insatisfacción corporal asociada al ideal de belleza, los resultados de las investigaciones mostraron que la insatisfacción corporal se producía cuando hombres y mujeres intentaban asemejar su imagen corporal con el ideal de belleza y que, la insatisfacción que mostraba cada género, difería en base a los modelos estéticos corporales para hombres (impulso hacia la musculatura) y mujeres (impulso hacia la delgadez).

En este caso, el $22.22 \%$ de las investigaciones encontraron en los hombres un mayor deseo por aumentar su masa muscular y, en las mujeres, por bajar de peso (Ejike, 2015; Forrester-Knauss \& Stutz, 2012; Salgado \& Álvarez, 2018; Zaccagni et al., 2014).

Gillen y Lefkowitz (2012) consideraron que los cuerpos de las mujeres estaban culturalmente objetivados y, que la auto-objetivación, puede conducir a esta población a ser excesivamente críticas con sus cuerpos, realizando una evaluación de apariencia más pobre que los hombres. Además, Zueck et al. (2016), atribuyeron a que los estándares de 'belleza y delgadez' son mucho más rígidos para las mujeres que para los hombres.

En último lugar, con el objetivo de explorar la influencia de diferentes vari-ables respecto a la insatisfacción corporal asociada al ideal de belleza, de manera global, el género fue una variable más significativa que la edad (Esnaola et al., 2010). Sin embargo, éstas no fueron las únicas variables predictoras de la insatisfacción corporal que encontraron las investigaciones.

En la población femenina se obtuvo como predictores de insatisfacción corporal: el bajo peso, el tabaquismo, la etnia y la actividad física (Arbinaga et al., 2011; Forrester-Knauss \& Stutz, 2012; Zaccagni et al., 2014). Mientras que, para ambos los géneros, el comportamiento alimenticio desordenado se mostró como un predictor significativo para la insatisfacción corporal (Chng \& Fassnacht, 2016; González et al., 2013). 
Otras variables que mostraron evidencia para el desarrollo de insatisfacción corporal fueron los comentarios parentales respecto a la imagen corporal para ambos géneros en población asiática (Chng \& Fassnacht, 2016), la práctica de deporte y actividad física (Arbinaga et al., 2011; Forrester-Knauss \& Stutz, 2012), el IMC (Bucchianeri et al., 2013) o variables psicológicas como el perfeccionismo (Siegling \& Delaney, 2013) y la baja autoestima (Zaccagni et al., 2014) como variables mediadoras o moderadoras para el desarrollo de insatisfacción corporal.

\section{Discusión}

En el $72.22 \%$ de las investigaciones analizadas, los resultados mostraron que son las mujeres quienes reflejaron un mayor nivel de insatisfacción corporal respecto a los hombres, con el deseo de querer adelgazar y bajar de peso para ajustar su imagen corporal a los modelos estéticos corporales e ideales de belleza en pro de la delgadez promovidos por los medios de comunicación. Resultados en línea a lo ya reportado por revisiones anteriores sobre la insatisfacción corporal asociada al ideal de belleza (Mancilla et al., 2012; McCabe \& Ricciardelli, 2004).

Sin embargo, debemos ser prudentes a la hora de interpretar los resultados dado que en tales investigaciones coincide que no existió un equilibrio entre el número de mujeres y hombres que conformaron las muestras (siendo significativamente mayor el volumen de población femenina estudiada en contraposición a la masculina). Una de las posibles razones puede encontrarse en que a lo largo de la historia han sido las mujeres quienes se han considerado como el grupo de mayor vulnerabilidad y riesgo para desarrollar sintomatología a los TCA (Amaya et al., 2010; Laus et al., 2014). Mientras que los estudios que sí tuvieron en cuenta las limitaciones de las muestras respecto a la proporción de mujeres y hombres seleccionado, obtuvieron que la población masculina también se siente insatisfecha con su imagen corporal manifestando, como las mujeres, un mayor deseo por perder peso o mantenerse delgados, junto con el deseo de querer aumentar su índice de masa muscular. En relación a este último aspecto, podemos mencionar además que, durante el siglo XXI, el culto al cuerpo ha contribuido a que hayan aumentado otros trastornos asociados más característicos de la población masculina en asociación a una insatisfacción corporal como son el caso de la Dismorfia Muscular (DM) o Vigorexia. El cual se caracteriza, principalmente, por la obsesión por alcanzar la perfección corporal mediante el desarrollo de masa muscular (Rodríguez-Molina \& Rabito-Alcón, 2011).

Otro aspecto significativo, fue que el por encima del $50 \%$ de las investigaciones analizadas fueron realizadas con grupos universitarios, lo que limita la generalización de los resultados a otros grupos.

Podemos observar, a nivel general, que las investigaciones midieron la insatisfacción corporal como un índice global, sin distinguir las diferencias que pudiera haber entre mujeres y hombres. Globalmente, aproximadamente el $60 \%$ de las muestras seleccionadas expresaron sentirse insatisfechas con su cuerpo. Resultados que para Zueck et al. (2016) corroboran que la insatisfacción corporal 
se trata de un problema de salud que predispone para el desarrollo de ciertos trastornos como los TCA o la DM (Compte \& Sepúlveda, 2014).

Respecto al escenario de las investigaciones, la mayor parte de los estudios analizados tuvieron su procedencia de Europa y EE. UU, lo que en parte se explica porque solo fueron seleccionadas las publicaciones en castellano e inglés. Sin embargo, investigaciones pasadas, refirieron un aumento de la prevalencia de los TCA, especialmente, en países desarrollados o en vías de desarrollo. Mientras que, en países del tercer mundo, todavía resulta un problema prácticamente inexistente (Ministerio de Sanidad y Consumo, 2009). El aumento de tal prevalencia, también puede relacionarse con el aumento progresivo de las investigaciones desarrolladas entre los años 2010 y 2018 . No obstante, es importante resaltar que cada vez son más frecuentes los casos de TCA en países en vías de desarrollo. Un posible reflejo de este hecho puede ser el incremento del número de investigaciones en países de Sudamérica como México y Colombia, sin olvidarnos de Singapur o Irán, país desde el que Garrusi y Baneshi (2017) señalan que el énfasis en las investigaciones sobre insatisfacción corporal se ha vuelto más frecuente entre otras sociedades, así como en las culturas occidentales que entre grupos de edad o diferencias de género.

Todo ello vendría a demostrar que la insatisfacción corporal no se trata solo de un problema de salud enmarcado en una cultura concreta, sino que posiblemente éste se está extendiendo a nivel global ante el aumento de las tecnologías, medios de comunicación y redes sociales (Garrusi \& Baneshi, 2013).

En cuanto a las herramientas utilizadas para medir insatisfacción corporal asociada al ideal de belleza, existen diferencias respecto a los instrumentos empleados por las investigaciones analizadas. En su gran mayoría, utilizaron herramientas de auto-reporte, es decir, aquellos instrumentos que son cumplimentados por la propia persona quien responde a los ítems formulados para medir la insatisfacción corporal a través de la valoración que hace de sí misma. Uno de los posibles motivos de su uso puede atribuirse a que este tipo de instrumentos permite evaluar a un gran número de personas o muestras, obteniendo un alto volumen de datos, en cortos periodos de tiempo. Sin embargo, se trata de herramientas enfocadas principalmente a población femenina y/o adolescente, lo que puede dificultar la comprensión de los ítems o la identificación con los aspectos evaluados por parte de la población masculina.

Respecto a las herramientas de siluetas o escalas visuales, únicamente tienen en cuenta modelos que van desde cuerpos delgados a cuerpos con sobrepeso, no incluyendo entre las siluetas modelos con una masa muscular más desarrollada. En este caso, ello pudo haber generado un sesgo en las investigaciones al no haber teniendo en cuenta las diferencias de género $\mathrm{y}$, por otro lado, al equiparar la distorsión con la imagen corporal, que es lo que miden principalmente este tipo de instrumentos como es el FRS, con la insatisfacción corporal. En este sentido, sería interesante revisar e incorporar a tales escalas nuevas siluetas y modelos con formas más musculadas, que reflejaran y se asemejaran a los modelos estéticos corporales que la sociedad de hoy en día promueven. Posiblemente, la elaboración y diseño por parte del $18 \%$ de las investigaciones analizadas de cuestionarios ad 
hoc, tuviera como finalidad obtener información que con este tipo de herramientas se queda incompleta y, de este modo, ampliar los datos más allá de la percepción a la valoración que la propia persona tiene en relación a su in/satisfacción corporal. Además, ser prudentes a la hora de evaluar la insatisfacción corporal con herramientas dirigidas a la distorsión con la imagen corporal por tratarse éstos de aspectos diferentes y no sinónimos.

No obstante, éstas no fueron las únicas metodologías de evaluación utilizados para medir la insatisfacción corporal. Forrester-Knauss y Stutz (2012) basan su investigación en los resultados obtenidos mediante encuesta telefónica analizando posteriormente los datos de manera cuantitativa, lo que favorece la obtención de un alto volumen de datos.

En relación a los principales factores precipitantes de la insatisfacción corporal asociada al ideal de belleza, son diferentes las variables tenidas en cuenta en las distintas investigaciones. Existiendo consenso entre los resultados obtenidos por las actuales investigaciones en relación a la literatura anterior (Alacid, LópezMiñarro, Muyor, \& Vaquero-Cristobal, 2013).

Concretamente, la influencia sociocultural, es el factor que reportó una mayor influencia, al llevar a las personas a compararse con los modelos estéticos corporales promovidos por los medios de comunicación y la presión de los mismos. Siendo las discrepancias con éstos los que parecen favorecer los sentimientos de insatisfacción con la propia imagen corporal $\mathrm{y}$, como resultado, lo que aumenta el riesgo de querer modificar o ajustar la imagen a dichos modelos (Esnaola et al., 2010).

Para Salcedo (2016), ello puede deberse a la frecuente necesidad de ser aceptados socialmente y, en consecuencia, el deseo de tener un cuerpo atractivo para los demás. En el caso de los hombres, como en el de las mujeres, tener una imagen corporal cercana al ideal de belleza se asocia también a otras características positivas como el éxito o el ser una persona saludable (Raich, 2000; Vaquero et al., 2014).

Por tanto, parece que el alejamiento de la imagen corporal de lo considerado ideal, con la consiguiente insatisfacción corporal, provoca que los sujetos busquen disminuir su peso o modificar su figura ejecutando determinadas CAR (Conductas alimentarias de riesgo) como medio para alcanzar el ideal de delgadez promovido socialmente (Berengüí et al., 2016).

Mientras que, el ejercicio físico, se trataría de una variable moderadora o mediadora en relación al desarrollo de insatisfacción corporal, mostrando aquellas personas que practican con mayor frecuencia cualquier tipo de deporte o actividad física, una mayor satisfacción hacia su imagen corporal (Arbinaga et al., 2011; González et al., 2013; Zaccagni et al., 2014), hallazgo ya reportado con anterioridad (Gómez \& Veiga, 2007).

Por último, en relación a la edad, se observó que las investigaciones trabajaron en su mayoría con poblaciones de jóvenes adultos con edades comprendidas entre los 18 y los 25 años. Únicamente, el 18\% de los estudios analizados, reportaron datos de muestras mayores a tales edades. Una posible razón de ello puede encontrarse en que tanto la insatisfacción corporal como la percepción de la 
influencia de diferentes factores socioculturales disminuyen en los grupos de edad avanzada, aunque en algunos casos esta disminución es solo muy pequeña (Esnaola et at., 2010). Por lo que la insatisfacción corporal parece que continúa aumentando hasta la edad adulta pero que, con el tiempo, esta insatisfacción se acaba manteniendo o, por el contrario, disminuye (Bucchianeri et al., 2013; Gillen \& Lefkowitz, 2012).

En base a los resultados encontrados por las diferentes investigaciones analizadas, podemos concluir que:

(1) La población femenina en relación a la masculina, continúa mostrando niveles más altos de insatisfacción corporal. Sin embargo, la población masculina también se muestra insatisfecha con su imagen corporal.

(2) Las diferencias de género versan en que los hombres además de desear perder peso buscan aumentar su masa muscular. Es decir, las mujeres estarían buscando alcanzar un cuerpo delgado, mientras que los hombres un cuerpo delgado y con músculo.

(3) El género se trata de una variable significativa a tener en cuenta respecto a la predisposición a desarrollar insatisfacción corporal asociada al ideal de belleza.

(4) Las variables socioculturales y el deseo por ajustarse a los modelos estéticos corporales promovidos por los medios de comunicación y la publicidad se tratan de los factores que mayor influencia ejercen en el desarrollo de insatisfacción corporal.

(5) La actividad física actúa como una variable moderadora o mediadora en el desarrollo de insatisfacción corporal.

(6) La edad influye en el mantenimiento de la insatisfacción corporal, la cual, parece disminuir a lo largo de los años.

(7) La insatisfacción corporal asociada al ideal de belleza no se trata de un problema de salud asociado a una cultura concreta, sino que es posible que se esté extendiendo por todo el mundo ante el aumento de las tecnologías, medios de comunicación y redes sociales a nivel global.

(8) Por último, la necesidad de considerar la variable de género para el diseño de las investigaciones e intervenciones que tengan como objetivo la insatisfacción corporal asociada al ideal de belleza.

Entre las limitaciones de este trabajo, podría señalarse la selección únicamente de los trabajos disponibles en texto completo utilizados para el desarrollo de la revisión sistemática además de la exclusión de publicaciones en idiomas difer-entes al castellano y el inglés. De cara al futuro y frente a próximas revisiones, sería interesante poder aumentar el número de fuentes y bases de datos empleadas para la búsqueda de artículos, así como seleccionar trabajos elaborados en otros idiomas además de en inglés y en español. De este modo, se aumentaría la minuciosidad de los datos y, como resultado, el conocimiento sobre la insatisfacción corporal asociada al ideal de belleza. 
Otra posible limitación de la revisión, fue el bajo número de publicaciones encontradas con población adulta no clínica. En este caso, si tenemos en consideración el número de investigaciones obtenidas en total $(2,292)$, frente a los 18 estudios finalmente seleccionados, podemos detectar que se trata de una parte de la población todavía poco estudiada, pudiendo ser interesante dirigir las futuras investigaciones a tal población con fines preventivos y no tanto a la población clínica de la que ya disponemos de un mayor conocimiento científico.

Como futuras propuestas y debido al alto número de personas que muestran insatisfacción con su imagen corporal, junto con el riesgo que conlleva para la salud ante la posible aparición de un TCA o conductas compensatorias que podrían poner el riesgo la salud, se hace necesario continuar profundizando en el presente tema atendiendo a las diferencias de género encontradas entre mujeres y hombres respecto a su satisfacción/insatisfacción corporal.

Por ejemplo, mediante la creación de nuevas herramientas o validación de las ya existentes en población masculina y adulta a través de las cuales poder evaluar las diferencias de género respecto a la insatisfacción corporal.

La combinación de metodologías de estudio de carácter cuantitativo con metodologías de estudio de carácter cualitativo como, por ejemplo, las entrevistas o grupos de discusión, podría tratarse de otro aspecto a poder incorporar en futuras investigaciones. La combinación de ambos métodos, permitiría poder conocer de primera persona los testimonios y valoraciones de las personas que sufren insatisfacción corporal asociada al ideal de belleza y enriquecer los datos obtenidos hasta el momento.

A partir de todo ello, trabajar hacia el diseño de programas de prevención e intervención ajustados a las diferencias de género, así como de promoción de la actividad física dirigidos a la prevención de la aparición y desarrollo de la insatisfacción corporal.

A modo de conclusión, se pudo comprobar que cada vez son mayores las tasas y niveles de insatisfacción que la población general manifiesta hacia su propia imagen corporal ante el deseo de querer ajustar ésta hacia modelos de belleza que ponen en riesgo la salud. En base a ello y a nivel social, sería interesante dirigir también la atención hacia los medios de comunicación y, sobre todo, hacia la publicidad, por ser éstas una de las principales fuentes de influencia sociocultural. Una forma de poder alcanzar este propósito podría ser el desarrollo de campañas dirigidas a la promoción de la salud e instauración de hábitos saludables en la sociedad que favorezcan, en general, el bienestar y la aceptación personal. En las que el mensaje principal que se transmita y promueva vaya dirigido a la 'salud' y no tanto a la 'belleza'.

\section{Disclosure statement}

No potential conflict of interest was reported by the authors/ Los autores no han referido ningún potencial conflicto de interés en relación con este artículo.

\section{ORCID}

Adriana Sobrino-Bazaga (D) http://orcid.org/0000-0002-9616-8670

María F. Rabito-Alcón (D) http://orcid.org/0000-0003-3524-5481 


\section{References / Referencias}

Acosta, M. V., \& Gómez-Peresmitré, G. (2003). Insatisfacción corporal y seguimiento de dieta. Una comparación transcultural entre adolescentes de España y México. Internacional Journal of Clinical and Health Psychology, 3, 9-21.

Alacid, F., López-Miñarro, P. A., Muyor, J. M., \& Vaquero-Cristobal, R. (2013). Imagen corporal: Revisión bibliográfica. Nutrición Hospitalaria, 28, 27-35.

Amaya, A., Álvarez, G. L., \& Mancilla, J. M. (2010). Insatisfacción corporal en interacción con autoestima, influencia de pares y dieta restrictiva: Una revisión. Revista Mexicana de Trastornos Alimentarios, 1, 79-89.

Arbinaga, F., García, D., Vázquez, I., Joaquín, M., \& Pazos, E. (2011). Actitudes hacia el ejercicio en estudiantes universitarios: Relaciones con los hábitos alimenticios y la insatisfacción corporal. Revista Iberoamericana de Psicología del Ejercicio y el Deporte, 6, 97-112.

Baile, J. I. (2003). ¿Qué es la imagen corporal? Cuadernos del Marqués de San Adrián: Revista de Humanidades, 2, 53-70.

Baile, J. I., Raich, R. M., \& Garrido, E. (2003). Evaluación de insatisfacción corporal en adolescentes: Efecto de la forma de administración de una escala. Anales de Psicología, 19, 187-192.

Baile, J. I., \& Velázquez-Castañeda, A. (2006). Medición del riesgo de trastorno alimentario en una muestra de mujeres mexicanas: Convergencia de tres técnicas de evaluación. Revista Mexicana de Psicología, 23, 225-233.

Berengüí, R., Castejón, M., \& Torregrosa, M. S. (2016). Insatisfacción corporal, conductas de riesgo para trastornos de la conducta alimentaria en universitarios. Revista Mexicana de Trastornos Alimentarios, 7, 1-8.

Bucchianeri, M. M., Arikian, A. J., Hannan, P. J., Eisenberg, M. E., \& Neumark-Sztainer, D. (2013). Body dissatisfaction from adolescence to young adulthood: Findings from a 10-year longitudinal study. Body Image, 10, 1-7.

Bully, P., Elosua, P., \& López-Jáuregui, A. (2012). Insatisfacción corporal en la adolescencia: Evolución en una década. Anales de Psicología, 28, 196-202.

Cash, T. F. (2000). Multidimensional body-self relations questionnaire (MBSRQ). Norfolk, VA: Author.

Cash, T. F., \& Pruzinsky, T. (2002). Body Image: A handbook of theory, research and clinical practice. New York, NY: Guilford Press.

Chng, S. C., \& Fassnacht, D. B. (2016). Parental comments: Relationship with gender, body dissatisfaction, and disordered eating in Asian young adults. Body Image, 16, 93-99.

Compte, E. J., \& Sepúlveda, A. R. (2014). Dismorfia muscular: Perspectiva histórica y actualización en su diagnóstico, evaluación y tratamiento. Psicología Conductual, 22, 307.

Cooper, P. J., Taylor, M. J., Cooper, Z., \& Fairbum, C. G. (1987). The development and validation of the Body Shape Questionnaire. International Journal of Eating Disorders, 6, 485-494.

Corral, S., González, M., Pereña, J., \& Seisdedos, N. (1998). EDI-2, Inventario de trastornos de la conducta alimentaria. Madrid: TEA.

Cruz, S., \& Maganto, C. (2008). TSA. Test de Siluetas para Adolescentes. Madrid: TEA.

Ejike, C. E. (2015). Body shape dissatisfaction is a 'normative discontent' in a youngadult Nigerian population: A study of prevalence and effects on health-related quality of life. Journal of Epidemiology and Global Health, 5(4), 19-26.

Elosua, P., López-Jáuregui, A., \& Sánchez-Sánchez, F. (2010). Adaptación española del eating disorder inventory-3. Normalización y validación. Madrid: TEA.

Elosua, P., \& Muñiz, J. (2010). Exploring the factorial structure of the self-concept: A sequential approach using CFA, MIMIC and MACS models, across gender and two languages. European Psychologist, 15, 58-67. 
Esnaola, I. (2005). Imagen corporal y modelos estéticos corporales en la adolescencia y la juventud. Análisis y Modificación de Conducta, 31, 6-22.

Esnaola, I., Rodríguez, A., \& Goñi, A. (2010). Body dissatisfaction and perceived sociocultural pressures: Gender and age differences. Salud Mental, 33(1), 21.

Espósito, D. H. (2015). Influence of prevalent aesthetic body model and body dissatisfaction in high school students. Revista Mexicana de Trastornos Alimentarios, 6, 91-96.

Fassnacht, D. B. (2007). Multifactorial measurement of eating disorders: Construction and validation of the Clinical and Research Inventory for Eating Disorders (CR-EAT). Unpublished doctoral dissertation, University of Tubingen, Germany.

Forrester-Knauss, C., \& Stutz, E. Z. (2012). Gender differences in disordered eating and weight dissatisfaction in Swiss adults: Which factors matter? BMC Public Health, 12. doi:10.1186/1471-2458-12-809

Garner, D. M. (1990). The eating disorder inventory 2. Odessa: Psychological Assessment Resources.

Garner, D. M. (2004). EDI 3: Eating disorder inventory-3: Professional manual. Odessa: Psychological Assessment Resources.

Gardner, R. M., Stark, K., Jackson, N., \& Friedman, B. N. (1999). Development and validation of two new scales for assessment of body image. Perception Motivation. Skills, 87, 981-983.

Garrusi, B., \& Baneshi, M. R. (2013). Eating Disorders and Their Associated Risk Factors among Iranian Population-A Community-Based Study. Global Journal of Health Science, 5(1), 193.

Garrusi, B., \& Baneshi, M. R. (2017). Body dissatisfaction among Iranian youth and adults. Cadernos d Saude Publica, 28(33), 9.

Gillen, M. M., \& Lefkowitz, E. S. (2012). Gender and racial/ethnic differences in body image development among college students. Body Image, 9, 126-130.

Gómez, D. M., \& Veiga, O. L. (2007). Insatisfacción corporal en adolescentes: Relaciones con la actividad física e índice de masa corporal. Revista Internacional de Medicina y Ciencias de la Actividad Física y del Deporte, 27, 253-265.

González, R., García, P., \& Martínez, J. (2013). Valoración de la imagen corporal y de los comportamientos alimentarios en universitarios. Revista de Psicopatología y Psicología Clínica, 18, 45-59.

Laus, M. F., Kakeshita, I. S., Costa, T. M. B., Ferreira, M. E. C., Fortes, L. D. S., \& Almeida, S. S. (2014). Body image in Brazil: Recent advances in the state of knowledge and methodological issues. Revista de Saude Publica, 48(2), 331-346.

Magallares, A. (2016). Eating concerns, body dissatisfaction, thinness internalization and antifat attitudes and their relationship with gender ideology in a sample of men. Anales de Psicología, 32, 167-173.

Mancilla, A., Vázquez, R., Mancilla, J. M., Amaya, A., \& Álvarez, G. (2012). Insatisfacción corporal en niños y preadolescentes: Una revisión sistemática. Revista Mexicana de Trastornos Alimentarios, 3, 62-79.

McCabe, M. P., \& Ricciardelli, L. A. (2004). Body image dissatisfaction among males across the lifespan: A review of past literature. Journal of Psychosomatic Research, $56,675-685$.

Mciza, Z., Goedecke, J. H., Steyn, N. P., Charlton, K., Puoane, T., Meltzer, S., \& Labert, E. V. (2005). Development and validation of instruments measuring body image and body weight dissatisfaction in South African mothers and their daughters. Public Health Nutricion, 8, 509-519.

Ministerio de Sanidad y Consumo. (2009). Guía de práctica clínica sobre trastornos de la conducta alimentaria. Barcelona: Agencia de Evaluación de Tecnología e Investigaciones Médicas de Cataluña. 
Mintem, G. C., Gigante, D. P., \& Horta, B. L. (2015). Change in body weight and body image in young adults: A longitudinal study. BMC Public Health, 15. doi:10.1186/ s12889-015-1579-7

Moessner, M., Fassnacht, D. B., \& Bauer, S. (2015). Online assessment of eating disorders: The clinical and research inventory for eating disorders (CR-EAT). Mental Health \& Prevention, 3, 170-177.

Oliveira, V., \& Parra, J. (2014). Imagen corporal y percepción de la influencia de los medios de comunicación: Diferencias de género en una muestra de adolescentes. Revista Inter Acción, 39, 461-478.

Pingitore, R., Spring, B., \& Garfieldt, D. (1997). Gender differences in body satisfaction. Obesity Research, 5, 402-409.

Rabito-Alcón, M. F., \& Rodríguez-Molina, J. M. (2015). Body image in persons with gender dysphoria. Medwave, 15, 04.

Rabito-Alcón, M. F., \& Rodríguez-Molina, J. M. (2016). Body dissatisfaction differences and similarities among people with eating disorders, people with gender dysphoria and university students. Revista de Psicopatología y Psicología Clínica, 21, 97-104.

Raich, R. M. (2000). Imagen corporal. Conocer y valorar el propio cuerpo. Madrid: Ediciones Pirámide.

Raich, R. M. (2004). Una perspectiva desde la psicología de la salud de la imagen corporal. Avances en Psicología Latinoamericana, 22, 15-27.

Ricciardelli, L. A., \& McCabe, M. P. (2002). Psychometric evaluation of the Body Change Inventory: An assessment instrument for adolescent boys and girls. Eating Behaviors, 3, 45-59.

Rodríguez-Molina, J. M., \& Rabito-Alcón, M. F. (2011). Vigorexia: De la adicción al ejercicio a entidad nosológica independiente. Health and Addictions, 11, 95-114.

Rodríguez-Ruiz, S., Díaz, S., Ortega-Roldán, B., Mata, J. L., Delgado, R., \& FernándezSantaella, M. C. (2013). La insatisfacción corporal y la presión de la familia y del grupo de iguales como factores de riesgo para el desarrollo de los trastornos de la conducta alimentaria. Anuario de Psicología Clínica y de la Salud, 9, 21-23.

Salcedo, S. (2016). Factores sociodemográficos, Índice de masa corporal (IMC) y satisfacción con la imagen corporal asociados a la conducta sexual de jóvenes estudiantes universitarios. Unpublished grade dissertation, Universidad Católica de Colombia, Colombia.

Salgado, M., \& Álvarez, J. (2018). Imagen corporal en universitarios del noreste de México: Estudio comparativo por sexo. Revista de Psicología de la Salud, 6(1), 58-86.

Salvador (2008). Cuestionario de creencias y estrategias para el control del peso. Unpublished manuscript, Universidad de Almería, Almería, España.

Salvador, M., García-Gálvez, C., \& de La Fuente, M. (2015). Creencias y estrategias para el control del peso, satisfacción con la imagen corporal y autoestima. European Journal of Education and Psychology, 3, 257-273.

Sepúlveda, A. R., Botella, J., \& León, J. A. (2001). La alteración de la imagen corporal en los trastornos de la alimentación: Un meta-análisis. Psicothema, 13, 7-16.

Siegling, A. B., \& Delaney, M. E. (2013). Toward understanding body image importance: Individual differences in a Canadian sample of undergraduate students. Eating Disorders, 21, 117-129.

Solano, N., \& Cano, A. (2010). Imagen. Evaluación de la insatisfacción con la imagen corporal. Madrid: TEA.

Stunkard, A. J., Sorensen, T., \& Schulsinger, F. (1983). Use of the Danish Adoption Register for the study of obesity and thinness. Research Publications-Association for Research in Nervous and Mental Disease, 60, 115.

Swiss Health Survey. (2007). The Swiss feel healthy. The Swiss Federal Office of Statistics. Retrieved from https://www.admin.ch/gov/en/start/documentation/mediareleases.msg-id-25409.html 
Thompson, M. A., \& Gray, J. J. (1995). Development and validation of a new body-image assessment scale. Journal of Personality Assessment, 64, 258-269.

Toro, J., Salmero, M., \& Martínez-Mallén, E. (1994). Assessment of sociocultural influences on the aesthetic body shape model in anorexia nerviosa. Acta Psychiatrica Scandinavica, 89, 147-151.

Trejo, P. M., Castro, D., Facio, A., Mollinedo, F. E., \& Valdez, G. (2010). Insatisfacción con la imagen corporal asociada al índice de masa corporal en adolescentes. Revista Cubana de Enfermería, 26, 150-160.

Trujano, P., Nava, C., Gracia, M. D., Limón, G., Alatriste, A. L., \& Merino, M. T. (2010). Trastorno de la imagen corporal: Un estudio con preadolescentes y reflexiones desde la perspectiva de género. Anales de Psicología, 26, 279-287.

Vaquero, A., Macias, O., \& Macazaga, A. (2014). La práctica corporal y la imagen corporal: Reconstruyendo significados. Revista Electrónica Interuniversitaria de Formación del Profesorado, 17(1), 163-176.

Vázquez, R., López- Aguilar, X., Álvarez- Rayón, G. L., Manzilla, J. M., \& Oliva A. (2006). Insatisfacción corporal e influencia de los modelos estéticos en niños y jóvenes varones mexicanos. Enseñanza e Investigación en Psicología, 11, 185-197.

Williamson, D. A., Womble, L. G., Zucker, N. L., Reas, D. L., White, M. A., Blouin, D. C., \& Greenway, F. (2000). Body image assessment for obesity (BIA-O): Development of a new procedure. International Journal of Obesity Related Metabolic Disorders, 24, 1326-1332.

Zaccagni, L., Masotti, S., Donati, R., Mazzoni, G., \& Gualdi-Russo, E. (2014). Body image and weight perceptions in relation to actual measurements by means of a new index and level of physical activity in Italian university students. Journal of Translational Medicine, 12. doi:10.1186/1479-5876-12-42

Zueck, M., Pinto, N. S., Pando, E. V. B., \& Guedea, J. C. (2016). Imagen corporal en universitarios mexicanos: Diferencias entre hombres y mujeres. Retos: Nuevas Tendencias en Educación Física, Deporte y Recreación, 30, 171-176. 